\title{
New method for assessing the susceptibility of glacial lakes to outburst floods in the Cordillera Blanca, Peru
}

\author{
A. Emmer and V. Vilímek \\ Department of Physical Geography and Geoecology, Faculty of Science, Charles University in Prague, \\ Prague, Czech Republic \\ Correspondence to: A. Emmer (aemmer@seznam.cz)
}

Received: 16 January 2014 - Published in Hydrol. Earth Syst. Sci. Discuss.: 26 February 2014

Revised: 16 July 2014 - Accepted: 7 August 2014 - Published: 9 September 2014

\begin{abstract}
This paper presents a new and easily repeatable method for assessing the susceptibility of glacial lakes to outburst floods (GLOFs) within the Peruvian region of the Cordillera Blanca. The presented method was designed to: (a) be repeatable (from the point of view of the demands on input data), (b) be reproducible (to provide an instructive guide for different assessors), (c) provide multiple results for different GLOF scenarios and (d) be regionally focused on the lakes of the Cordillera Blanca. Based on the input data gained from remotely sensed images and digital terrain models/topographical maps, the susceptibility of glacial lakes to outburst floods is assessed using a combination of decision trees for clarity and numerical calculation for repeatability and reproducibility. A total of seventeen assessed characteristics are used, of which seven have not been used in this context before. Also, several ratios and calculations are defined for the first time. We assume that it is not relevant to represent the overall susceptibility of a particular lake to outburst floods by one result (number), thus it is described in the presented method by five separate results (representing five different GLOF scenarios). These are potentials for (a) dam overtopping resulting from a fast slope movement into the lake, (b) dam overtopping following the flood wave originating in a lake situated upstream, (c) dam failure resulting from a fast slope movement into the lake, (d) dam failure following the flood wave originating in a lake situated upstream and (e) dam failure following a strong earthquake. All of these potentials include two or three components and theoretically range from 0 to 1 . The presented method was verified on the basis of assessing the pre-flood conditions of seven lakes which have produced ten glacial lake outburst floods in the past and ten lakes which have not. A comparison of these
\end{abstract}

results showed that the presented method successfully identified lakes susceptible to outburst floods (pre-flood conditions of lakes which have already produced GLOFs).

\section{Introduction}

\subsection{Phenomenon of GLOFs and the Cordillera Blanca}

Glacial lakes of all types represent a significant threat for the inhabitants of high-mountain regions worldwide (e.g. Clague et al., 2012; Evans and Clague, 1994; Iribarren et al., 2014), including the most heavily glacially covered tropical range of the world - the Cordillera Blanca of Peru (Carey, 2005; Vilímek et al., 2005). A sudden release of retained water causes floods, so-called "glacial lake outburst floods" GLOFs, which can easily transform into debris or mud flow movements (e.g. Breien et al., 2008; O'Connor et al., 2001). These extreme processes are characterised by discharges several times higher than the discharges reached during "classical" hydrometeorological floods (e.g. Cenderelli and Wohl, 2001; Costa and Schuster, 1988; Korup and Tweed, 2007). From the geomorphological point of view, these are one of the most significant fluvial-gravitational processes influencing glacial valleys in the period of deglaciation in high-mountain regions (Benn et al., 2012; Richardson and Reynolds, 2000a).

Since the end of the Little Ice Age, whose second peak culminated in the Cordillera Blanca in the 19th Century (Solomina et al., 2007; Thomson et al., 2000), catastrophic GLOFs originating from moraine-dammed and bedrockdammed lakes have claimed thousands of lives and caused 
considerable damage within the region of the Cordillera Blanca (e.g. Ames and Francou, 1995; Carey et al., 2012; Lliboutry et al., 1977; Zapata, 2002). Many of the largest lakes have been remediated since the early 1950s (Carey, 2005); however, the number of reported outburst floods has increased over the last decades. This fact is connected to the ongoing progressive deglaciation and to the associated increase in the overall number of lakes within the Cordillera Blanca (Emmer et al., 2014). Besides the formation and rapid evolution of new dangerous lakes, which is a result of glacier retreat (e.g. Quincey et al., 2007), the volume of already existing proglacial lakes often increases due to continuing glacier retreat beneath the water level or by lake deepening caused by melting of ice cores incorporated in submerged basal moraine (Vilímek et al., 2005). The greater the volume of water retained in the lake, the greater the volume of water available for potential flooding, depending on the cause and mechanism of water release (Westoby et al., 2014). Monitoring of glacier behaviour and repeated bathymetric measurements are thus quite important for registering the dynamic evolution of a particular lake.

Generally, there are three types of glacial lakes in the Cordillera Blanca, distinguished according to the dam material: (1) moraine dammed; (2) bedrock dammed; and (3) ice dammed. In this article, ice-dammed lakes are excluded because they are not significant in volume (in contrast to the high mountains of Central Asia; Hewitt, 1982; Iturrizaga, 2005) and thus do not represent a threat, hence there is no need to take them into account in this context.

There are several causes and mechanisms of GLOFs (e.g. Clague and Evans, 2000; Costa and Schuster, 1988; Grabs and Hanisch, 1993; Richardson and Reynolds, 2000a; Westoby et al., 2014). Fast slope movements into the lake (e.g. icefall, landslide, or rockfall) producing a displacement wave, which may overtop or break the lake dam (depending on the particular dam type), are the main cause of GLOFs within the region of the Cordillera Blanca (Emmer and Cochachin, 2013). GLOFs following large earthquakes and GLOFs occurring when a flood wave originating from a lake situated upstream reaches a downstream situated lake were also recorded in this region (Lliboutry et al., 1977; Zapata, 2002). It is clear that the occurrence of GLOFs is a highly complex issue, which, besides the lake and dam settings, is closely connected with the wider settings of the lake's surroundings (e.g. glaciological setting of the mother glacier, slope stability of moraines surrounding the lake, etc.). Assessing the possibility of GLOF occurrence (susceptibility of glacial lake to outburst floods) is thus quite a challenging scientific problem, which requires an interdisciplinary approach as well as cooperation.

\subsection{Previous research and existing methods for assessing the susceptibility of glacial lakes to outburst floods}

Several methods for assessing the susceptibility of glacial lakes to outburst floods can be found in the literature (Bolch et al., 2011; Clague and Evans, 2000; Costa and Schuster, 1988; Grabs and Hanisch, 1993; Gruber and Mergili, 2013; Huggel et al., 2002, 2004; McKillop and Clague, 2007a, b; Mergili and Schneider, 2011; O'Connor et al., 2001; Reynolds, 2003; Wang et al., 2008, 2011, 2012; Yamada, 1993). These methods distinguish themselves by type of method construction, number and selection of assessed characteristics, required input data and rate of subjectivity in assessment procedures (Emmer and Vilímek, 2013). Some of them are regionally focused and some are designed to be adaptable. The demands on the input data and the rate of subjectivity of assessment procedures are generally considered as the fundamental obstructions to their repeated use. Emmer and Vilímek (2013) examined the suitability of these methods for use within the Cordillera Blanca. It was shown that none of the applied methods meet all of the specified criteria; therefore, a new method is desirable (see Sect. 1.3). Once lakes susceptible to outburst floods are identified, flood modelling and delimitation of endangered areas are the next steps in the risk management procedure (Westoby et al., 2014; Worni et al., 2013).

\subsection{Reasons and objectives of the study}

The reasons for the presented study are as follows: first, as shown in our previous research - existing methods are not wholly suitable for use within the Cordillera Blanca from the perspective of the assessed characteristics and the account of regional specifics (especially the share and representation of various triggers of GLOFs and climate settings; Emmer and Cochachin, 2013; Emmer and Vilímek, 2013). Second, the assessment procedures of the majority of these methods are at least partly subjective (based on an expert assessment without giving any thresholds, when a clear instructive guide is missing), thus different observers may reach different results even when the same input data are used. Repeated use is thus considerably limited and we consider this to be the fundamental drawback of the present methods as well as a research deficit.

Due to the above-mentioned reasons, the main objective of this work is to provide a comprehensive and easily repeatable methodological concept for the assessment of the susceptibility of glacial lakes within the Cordillera Blanca to outburst floods, verified on the glacial lakes and GLOFs recorded in this region. The impacts of glacial lake outburst floods cannot ever be completely eliminated; nevertheless, reliable assessment of the susceptibility of glacial lakes to outburst floods is a necessary step in the effective flood hazard and 
consequently risk management and mitigation. Therefore, it is of great importance.

\section{Creation of new method}

The presented method is designed to meet four principles which were considered as being crucial based on an analysis of the drawbacks of the existing methods (Emmer and Vilímek, 2013). The presented method is designed to (a) be repeatable (from the point of view of the demands on input data; all input data are gained from remotely sensed images and digital terrain models or topographical maps, there is no need for field survey); (b) be reproducible (the presented method provides an instructive guide for different assessors, which should obtain identical results should the same input data be used); (c) provide multiple results for different GLOF scenarios (more detailed view on the susceptibility of an assessed lake to outburst floods, which also allows individual characteristics important in each scenario to be targeted) and (d) be regionally focused on the lakes of the Cordillera Blanca (method verification on the lakes of this range).

Creation of a new method for assessing the susceptibility of glacial lakes to outburst floods generally requires four stages, which reflect the structure of the presented paper. These are: (1) selection of the type of construction of the method; (2) selection of the appropriate characteristics to be assessed (this stage includes analysis of regional specifics and also subordination to the data availability); (3) determination of thresholds and weightings of the assessed characteristics (it is essential to determine the thresholds (critical values) because of the reproducibility of the method used) and (4) method verification. Some steps in the construction of the presented method are, nevertheless, partly influenced by subjective expert experience and opinion (see also Sect. 4.1).

\subsection{Type of construction of the method}

Each method for assessing the susceptibility of glacial lakes to outburst floods usually has its own specific construction. Generally, we can distinguish between: (1) points-based methods, where susceptibility to GLOFs is indicated by the number of achieved points (e.g. Huggel et al., 2002; Reynolds, 2003); (2) calculation-based methods, where susceptibility to GLOFs is based on the results of defined calculations (e.g. McKillop and Clague, 2007b; Wang et al, 2011); (3) decision-tree-based methods, where an instructive graphical guide for assessment is given (e.g. the presented method); (4) matrix-based methods, which are usually used in combination with, for example, the point-based method and the overall susceptibility is derived from two or more components (e.g. Mergili and Schneider, 2011); and (5) their combinations. A combination of decision trees for clear illustrative representation of the assessment procedures and calculations for clarity and simple repeatability was used in the presented method.

Recorded mechanisms of GLOFs within the Cordillera Blanca of Peru (Emmer and Cochachin, 2013) have been shown to be dam overtopping or dam failure (only in case of moraine-dammed lakes), both following various triggers. Therefore, we feel it is necessary to strictly distinguish between these two dissimilar mechanisms in the assessment of the susceptibility of glacial lakes to outburst floods, because the processes affecting the characteristics and also volumes of released water significantly differ. Dam overtopping within the Cordillera Blanca has been described as a result of (a) fast slope movement into the lake or (b) flood wave from a lake situated upstream. Dam failures have been described as a result of (a) fast slope movement into the lake; (b) flood wave from a lake situated upstream or (c) a strong earthquake.

We feel it is not meaningful to describe the overall susceptibility of a particular lake to outburst floods with the use of a single number, as has been done by many authors before. The presented method thus assesses the potentials for the five above-mentioned scenarios separately, whereby providing five separate results. These results are designed as a product of two or three components for each scenario (Tale 1). Richardson and Reynolds (2000a) showed that it is necessary to include two components: (a) dam stability and (b) potential for initialising event. This more or less corresponds to the components presented in this method. It is clear that some of the scenarios include similar components, e.g. both Scenario 1 and Scenario 3 include the components "potential for fast slope movement into the lake" and "potential for dam overtopping by displacement wave"; however, Scenario 3 also includes the component "dam erodibility".

The obtained results theoretically range from 0 to 1 for each component and thus also from 0 (zero potential) to 1 (maximum potential) for each scenario. Naturally, this allows for both the identification of the most susceptible lakes and the most likely scenario of the outburst flood for a particular lake (scenario with the highest potential).

\subsection{Assessed characteristics and their thresholds}

According to the previous research (Emmer and Cochachin, 2013; Emmer and Vilímek, 2013), five essential groups of characteristics which need to be taken into account in a regionally focused method for assessing the susceptibility of glacial lakes to outburst floods within the Cordillera Blanca were estimated. These are groups of characteristics related to (a) the possibility of fast slope movement into the lake, (b) the distinction between a natural dam and a dam with remedial works (more generally dam stability), (c) the dam freeboard (ratio of dam freeboard), (d) the possibility of a flood wave from a lake situated upstream and (e) the possibility of a dam rupture following a large earthquake. 
Table 1. Scenarios of GLOFs and their components.

\begin{tabular}{|c|c|c|c|}
\hline Scenario & Description & Components & $\begin{array}{r}\text { Number of } \\
\text { assessed } \\
\text { characteristics }\end{array}$ \\
\hline \multirow[t]{2}{*}{ Scenario 1} & $\begin{array}{l}\text { Dam overtopping following fast } \\
\text { slope movement into the lake }\end{array}$ & $\begin{array}{l}\text { Potential for fast slope movement } \\
\text { into the lake }\end{array}$ & 6 \\
\hline & & $\begin{array}{l}\text { Potential for dam overtopping by } \\
\text { displacement wave }\end{array}$ & 2 \\
\hline \multirow[t]{2}{*}{ Scenario 2} & $\begin{array}{l}\text { Dam overtopping following a } \\
\text { flood wave originating in a lake } \\
\text { situated upstream }\end{array}$ & $\begin{array}{l}\text { Potential for flood wave from a lake } \\
\text { situated upstream }\end{array}$ & $17^{*}$ \\
\hline & & Retention potential of assessed lake & 4 \\
\hline \multirow[t]{3}{*}{ Scenario 3} & $\begin{array}{l}\text { Dam failure resulting from fast } \\
\text { slope movement into the lake }\end{array}$ & $\begin{array}{l}\text { Potential for fast slope movement } \\
\text { into the lake }\end{array}$ & 6 \\
\hline & & $\begin{array}{l}\text { Potential for dam overtopping by } \\
\text { displacement wave }\end{array}$ & 2 \\
\hline & & Dam erodibility for Scenario 3 & 4 \\
\hline \multirow[t]{3}{*}{ Scenario 4} & $\begin{array}{l}\text { Dam failure following the flood } \\
\text { wave originating in a lake situ- } \\
\text { ated upstream }\end{array}$ & $\begin{array}{l}\text { Potential for flood wave from a lake } \\
\text { situated upstream }\end{array}$ & $17^{1}$ \\
\hline & & Retention potential of assessed lake & 4 \\
\hline & & Dam erodibility for Scenario 4 & 6 \\
\hline \multirow[t]{2}{*}{ Scenario 5} & $\begin{array}{l}\text { Dam failure following strong } \\
\text { earthquake }\end{array}$ & Potential for strong earthquake & $0^{2}$ \\
\hline & & Dam instability & 5 \\
\hline
\end{tabular}

Individually assessed characteristics in the new method (requiring input data) were chosen to meet the following criteria: (1) they fit into the five above-mentioned groups of characteristics and (2) they are subordinated to data availability. Some of the characteristics were repeated in several of the scenarios (e.g. dam freeboard for Scenarios 1-4) and some are specific for an individual scenario (e.g. piping for Scenario 5). Most of the characteristics have already been mentioned in previous studies but we have also used seven characteristics which have not been mentioned in this context before (Table 2).

Objective determination of thresholds is quite a delicate scientific problem; on the other hand, it is highly desirable to determine all of the thresholds in order to eliminate the subjective component (presence of an "expert assessment") and for repeatability of the method (see also Sect. 4.1). We aimed to eliminate the need of threshold estimation, thus continuous variables and various ratios were used as much as possible. It is clear that it is not wholly possible to limit or quantify qualitative discrete variables (e.g. dam type, piping occurrence, or type of remedial work); therefore, qualitative discrete variables are used in the decision trees, but not in the calculations.

\subsection{Decision trees and calculations}

As we have explained above, five separate assessment procedures (decision trees) for five different GLOF scenarios are included in the presented method. These are (a) potential for dam overtopping resulting from a fast slope movement into the lake (see Sect. 2.3.1), (b) potential for dam overtopping following the flood wave originating in a lake situated upstream (see Sect. 2.3.2), (c) potential for dam failure resulting from fast slope movement into the lake (see Sect. 2.3.3), (d) potential for dam failure following the flood wave originating in a lake situated upstream (see Sect. 2.3.4) and (e) potential for dam failure following a strong earthquake (see Sect. 2.3.5). The first and second scenarios (dam overtopping) are possible for all lake types, whereas the other scenarios (dam failures) may occur exclusively in the case of moraine-dammed lakes. 
Table 2. Individually assessed characteristics (input data) used in the presented method.

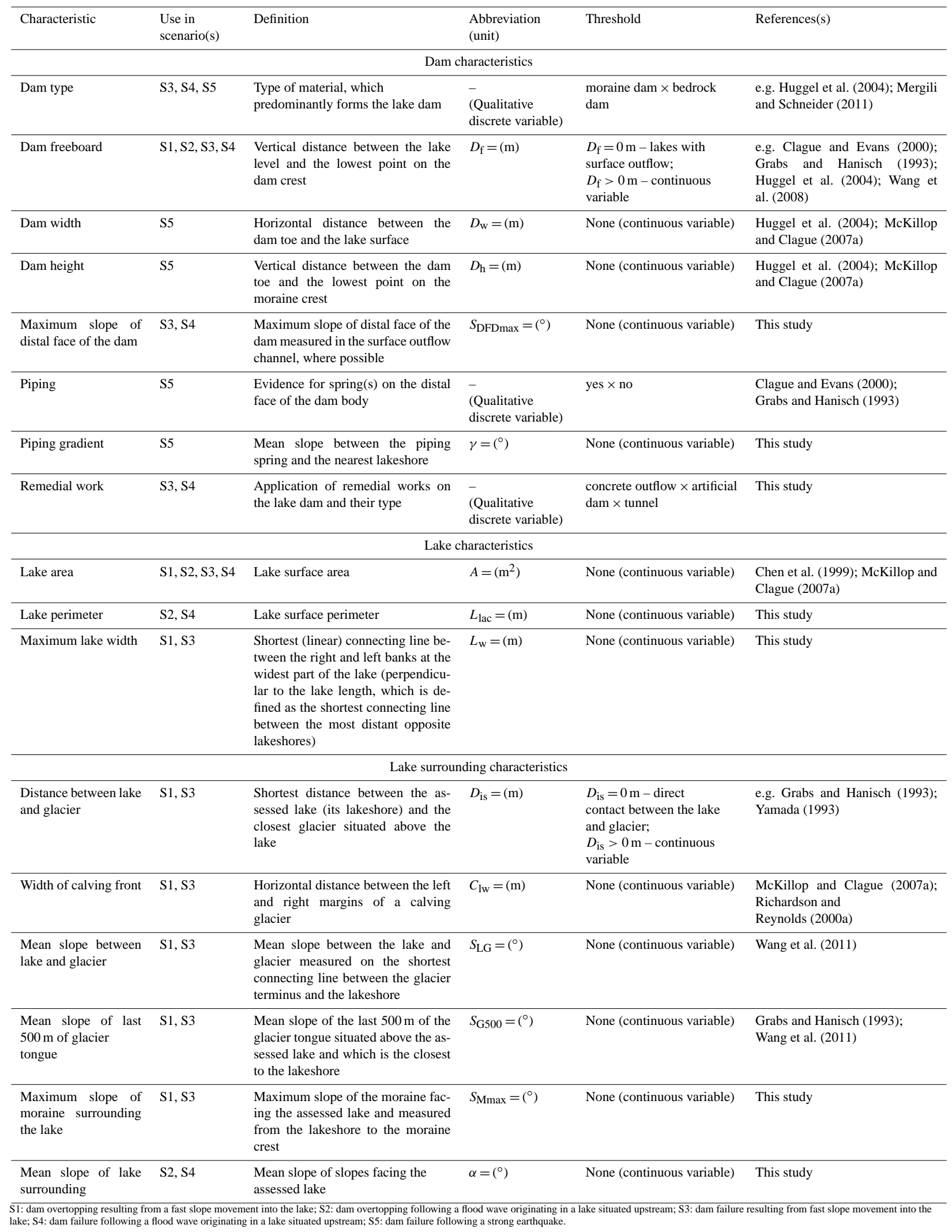




\subsubsection{Potential for dam overtopping resulting from fast slope movement into the lake (Scenario 1)}

It has been shown that GLOFs most frequently result from fast slope movement into the lake, producing a displacement wave (e.g. Costa and Schuster, 1998; Clague and Evans, 2000; Awal et al., 2010). There are two components that need to be taken into consideration when assessing the potential for Scenario 1. These are (a) potential for fast slope movement into the lake and (b) potential for dam overtopping by a displacement wave. The overall potential for Scenario 1 is consequently derived by combining both of these components.

The group of characteristics describing the first component includes characteristics related to the various types of fast slope movements, which may enter the lake and consequently cause a displacement wave resulting in dam overtopping. These are especially characteristics related to the possibility of (a) calving into the lake, (b) icefalls from hanging glaciers into the lake and (c) landslides on moraines surrounding the lake. Thus, the first component includes three subcomponents. For the final assessment of the Scenario 1, the higher subcomponent is used.

The first step in assessing the potential for icefall into the lake is to determine whether a glacier is situated above the lake or the valley is already completely deglaciated. If the valley is already completely deglaciated, the potential for icefall into the lake is naturally equal to 0 . If there are glaciers above the lake, the first of the assessed characteristics related to the potential for icefalls from calving or hanging glaciers into the lake is the distance between the lake and the glacier $\left(D_{\text {is }}=(\mathrm{m})\right)$. This characteristic provides information on whether the lake is in direct contact with the glacier (calving occurs) or not. If the assessed lake is in direct contact with a glacier $\left(D_{\text {is }}=0 \mathrm{~m}\right)$, then the ratio of the width of the calving front to the maximum lake width $\left(r_{C_{\mathrm{lw}} / \mathrm{Lw}}=\right.$ (unitless) $)$ is calculated as follows:

$r_{C_{\mathrm{lw}} / \mathrm{Lw}}=C_{\mathrm{lw}} / L_{\mathrm{w}}$

where $C_{\mathrm{lw}}$ is the width of the calving front $\left(C_{\mathrm{lw}}=(\mathrm{m})\right)$ and $L_{\mathrm{w}}$ is the maximum lake width $\left(L_{\mathrm{w}}=(\mathrm{m})\right)$. Ratio $r_{C_{\mathrm{lw}}} / \mathrm{Lw}$ is used to simplistically describe the potential for an appearance of a displacement wave(s) induced by the falling of part of the front of a calving glacier into the lake, with limited demand on input data (see Sects. 4.1, 4.3). It is clear that the potential increases with an increasing width of the calving front. In order to obtain a dimensionless value, we decided to relate the width of the calving front to the maximum lake width. The potential for icefall into the lake is equal to 1 if the ratio of the width of the calving front to the maximum lake width is equal or greater to 1 . If it is less than 1 , then the resulting value is used as the potential for icefall into the lake (Fig. 1).
If the lake is not in direct contact with the glacier $\left(D_{\text {is }}>0 \mathrm{~m}\right)$, the topographical susceptibility for icefall $\left(T_{\mathrm{SI}}=(\right.$ unitless $\left.)\right)$ should be calculated as follows:

$T_{\mathrm{SI}}=\sin \left(S_{\mathrm{LG}}\right) \cdot \sin \left(S_{\mathrm{G} 500}\right)$,

where the mean slope between the lake and the glacier $\left(S_{\mathrm{LG}}=\left(^{\circ}\right)\right)$ and the mean slope of the last $500 \mathrm{~m}$ of the glacier tongue $\left(S_{\mathrm{G} 500}=\left(^{\circ}\right)\right)$ are used. A sinus function was chosen to describe the non-linear increasing potential with increasing slope. The second reason for selecting a sinus function was that we believe that it is more important to stress the rapidly increasing susceptibility of the slopes between $0-60^{\circ}$ than between $60-90^{\circ}$ because moraine slopes steeper than $70^{\circ}$ frequently fail. For this reason a tangent function which stresses differences between steeper slopes was not used. We feel that it is not necessary to include the distance between the lake and the glacier in the equation, because the question of whether a broken block of ice will finally hit the lake or not is primarily controlled by the slope between the lake and the glacier. Moreover, the distance between the lake and the glacier is used in the previous step in the decision tree.

To assess the potential for a landslide of a moraine into the lake, it is first necessary to decide whether there are unstable moraine slopes in the lake surroundings. It is recommended to make a decision on the basis of manual expert analysis of high-resolution optical images, or geomorphological (geological) maps, if available. If there are moraines surrounding the lake, then the potential for a landslide into the lake is described by a single characteristic in the presented method, as follows:

$T_{\mathrm{SL}}=\sin \left(S_{\mathrm{Mmax}}\right)$,

where $S_{\mathrm{Mmax}}$ is the maximum slope of a moraine surrounding the lake $\left(S_{\mathrm{Mmax}}=\left(^{\circ}\right)\right)$. We suppose that the use of the maximum slope instead of the mean slope, which is generally used, is more representative for this assessment procedure, because the possibility of a landslide occurrence is generally not controlled by the mean slope but by the maximum slope. The decision tree describing the procedure for assessing the potential for fast slope movement into the lake provides three results: potential for calving into the lake, potential for icefall from hanging glaciers into the lake and potential for a landslide of a moraine into the lake. The higher value is typically used for the final assessment of the potential for dam overtopping following fast slope movement into the lake, but each of the values can be used to estimate the potential for each specific trigger.

The second component for assessing the potential for dam overtopping following fast slope movement into the lake is the potential for dam overtopping by a displacement wave. It is necessary to decide whether the displacement wave generated by the slope movement into the lake would overcome the dam freeboard $\left(D_{\mathrm{f}}-\right.$ vertical distance between the lake level and the lowest point on the dam crest; $D_{\mathrm{f}}=(\mathrm{m})$ ) or would be 


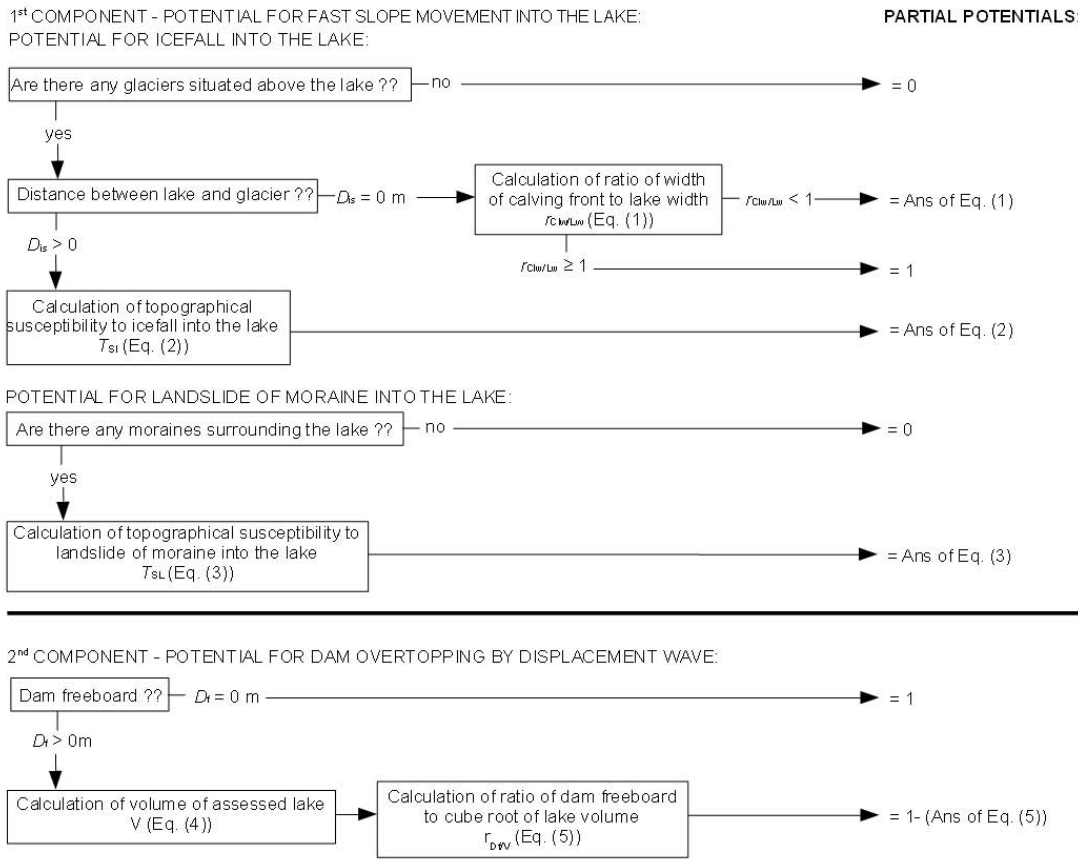

Figure 1. Decision tree for assessing the potential for dam overtopping resulting from a fast slope movement into the lake (Scenario 1). The overall potential is derived as a product of the highest partial potentials of the first and second components.

captured within the lake. The first step in this part of the decision tree is therefore an assessment of the dam freeboard. If the assessed lake has surface outflow $\left(D_{\mathrm{f}}=0 \mathrm{~m}\right)$, then the potential for dam overtopping following fast slope movement into the lake is maximum $(=1)$. If $D_{\mathrm{f}}>0 \mathrm{~m}$, the ratio of dam freeboard to the cube root of the lake volume $\left(r_{D_{\mathrm{f}} / V}\right)$ is calculated (see Eq. 5). This ratio was chosen for several reasons. First, this ratio provides a continuous variable therefore it is not necessary to determine any thresholds. Second, this ratio increases with increasing dam freeboard and decreases with the same dam freeboard and greater lake volume. Third, there is no need to estimate the volume of potential slope movement.

It is clear that the lake volume is an essential input value for the calculation of dam freeboard to the cube root of the lake volume ratio. The relation between lake surface area $\left(A=\left(\mathrm{m}^{2}\right)\right)$ and lake volume $\left(V=\left(\mathrm{m}^{3}\right)\right)$ of 35 glacial lakes of various types (both moraine-dammed lakes and bedrock-dammed lakes) and sizes (from $0.02 \times 10^{6}$ to $49.63 \times 10^{6} \mathrm{~m}^{3}$ ) within the Cordillera Blanca was used for this purpose. Input data were gained from Autoridad Nacional del Agua bathymetries (Cochachin et al., 2010; Cochachin and Torrés, 2011). The empirical power function formula for deriving lake volume $(V)$ from easily measured lake surface area $(A)$ was estimated as follows:

$V=0.054293 \cdot A^{1.483009}\left(r^{2}=0.927\right)$,

where $A$ is the lake surface area $\left(A=\left(\mathrm{m}^{2}\right)\right)$. This formula is used for calculating all of the lake volumes in the presented method because the bathymetry of the majority of the glacial lakes within the Cordillera Blanca is not measured. With this input data it is possible to calculate the ratio of dam freeboard to the cube root of lake volume $\left(r_{D_{\mathrm{f}} / V}=\right.$ (unitless)) as follows:

$r_{D_{\mathrm{f}} / V}=D_{\mathrm{f}} / V^{1 / 3}$,

where $D_{\mathrm{f}}$ is dam freeboard $\left(D_{\mathrm{f}}=(\mathrm{m})\right)$; and $V$ is lake volume $\left(V=\left(\mathrm{m}^{3}\right)\right.$; Eq. 4). The cube root function was used for the purpose of unifying the units.

\subsubsection{Potential for dam overtopping following the flood wave originating in a lake situated upstream (Scenario 2)}

An outburst flood following Scenario 2 is possible in the cascade systems of the lakes within the Cordillera Blanca. Hand in hand with ongoing deglaciation, new unstable lakes at high elevation about $5000 \mathrm{~m}$ a.s.l. are forming and rapidly growing (Emmer et al., 2014) and pose possible triggers for outburst floods from lakes situated downstream (large lakes in main valleys).

Assessment of the potential for Scenario 2 generally requires the following two components to be included: (a) retention potential of a lake situated downstream (assessed lake) and (b) potential for a flood wave from a lake situated upstream. Due to their interconnection and for reasons of clarity, both of these components are incorporated in the decision tree simultaneously (are not distinguished) (Fig. 2). 


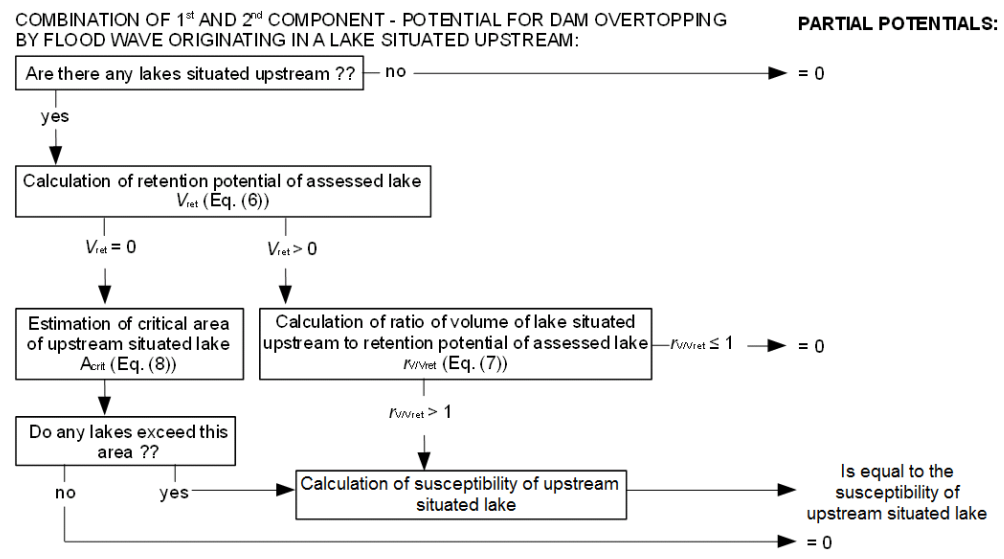

Figure 2. Decision tree for assessing the potential for dam overtopping following a flood wave originating in a lake situated upstream (Scenario 2).

The presented method is not designed to take into account the retention potential of the valley between two consecutive lakes. This is especially due to the fact that this question is quite complex and requires its own assessment procedure with high demands on input data. Therefore, we assume the distribution of all of the escaped water from the upstream situated lake into the downstream situated lake. If the upstream situated lake is considered to pose a threat to a downstream situated lake, then we recommend more detailed investigation in order to quantify the retention potential of the valley between these lakes and subsequently the flood modelling.

An assessment of the potential for Scenario 2 is only meaningful when the ratio of the upstream lake volume to downstream lake retention potential $\left(r_{V / V_{\mathrm{ret}}} ;=\right.$ (unitless)) is higher than 1 (see Fig. 2). This ratio describes whether the lake volume of the upstream situated lake is greater than the retention potential of the downstream situated (assessed) lake or not.

In this ratio, Eq. (4) is used for estimating the volume of the upstream situated lake(s). The second component of the ratio is the retention potential of a downstream situated (assessed) lake $\left(V_{\text {ret }}=\left(\mathrm{m}^{3}\right)\right)$. Based on a simplified geometric model of the lake, the formula for calculating the retention potential was estimated as follows:

$$
\begin{aligned}
V_{\text {ret }}=D_{\mathrm{f}} \cdot\left(6 A+D_{\mathrm{f}} \cdot \operatorname{tg}(90-\alpha)\right. \\
\left.\left(3 L \operatorname{lac}+2 \pi \cdot D_{\mathrm{f}} \cdot \operatorname{tg}(90-\alpha)\right)\right) / 6,
\end{aligned}
$$

where $D_{\mathrm{f}}$ is the dam freeboard $\left(D_{\mathrm{f}}=(\mathrm{m})\right) ; A$ is the lake surface area $\left(A=\left(\mathrm{m}^{2}\right)\right) ; L_{\mathrm{lac}}$ is the lake perimeter $\left(L_{\mathrm{lac}}=(\mathrm{m})\right)$; $\alpha$ is the mean slope of the lake surroundings $\left(\alpha=\left(^{\circ}\right)\right.$ ). Equation (6) is used to quantify the maximum absorbable volume of water before the dam crest is reached (the retention potential of the lake), assuming a gradual increase in water level (not assuming the possibility of the appearance of a significant displacement wave caused by the flood wave from the upstream situated lake). The ratio of the upstream lake volume to the downstream lake retention potential has the following form:

$r_{V / V_{\text {ret }}}=V / V_{\text {ret }}$,

where $V$ is the volume of the lake situated upstream $\left(V=\left(\mathrm{m}^{3}\right)\right.$; Eq. 4), and $V_{\text {ret }}$ is the retention potential of the lake situated downstream $\left(V_{\text {ret }}=\left(\mathrm{m}^{3}\right)\right.$; Eq. 6$)$. The result of the upstream lake volume to downstream lake retention potential ratio calculation is limited: $0<r_{V / V_{\text {ret }}}<\infty$. If the lake volume of the lake situated upstream is higher than the retention potential of the lake situated downstream $\left(r_{V / V_{\text {ret }}}>\right.$ $1)$, then the flood wave originating from this upstream lake may subsequently also cause an outburst flood from the lake situated downstream. In this case, it is necessary to assess the susceptibility of the upstream situated lake to an outburst flood separately. The potential for dam overtopping is therefore equal to the susceptibility of the upstream situated lake to outburst flood (the whole assessment procedure is needed). In cases where the retention potential of a downstream situated lake is higher than the volume of upstream situated lake, the potential flood wave would be absorbed by the downstream situated lake and the potential for dam overtopping is thus equal to zero (Fig. 2).

It is clear that the calculation of $r_{V / V_{\text {ret }}}$ is not relevant for lakes with surface outflow $\left(D_{\mathrm{f}}=0 \mathrm{~m} ; V_{\text {ret }}=0 ; r_{V / V_{\text {ret }}} \rightarrow\right.$ $\infty)$. In these cases, it is necessary to estimate the minimal volume or the critical lake area $\left(A_{\text {crit }}=\left(\mathrm{m}^{2}\right)\right)$, which needs a separate assessment procedure (to avoid assessing all of the small lakes situated upstream). For this purpose, a simple equation was estimated:

$A_{\text {crit }}=0.05 \cdot A$,

where $A$ is the surface area of the assessed lake $\left(A=\left(\mathrm{m}^{2}\right)\right)$. A constant (0.05) was chosen on the basis of analyzing previous events (e.g. the 2012 event in Artizon (Santa Cruz) valley; Emmer et al., 2014) and expert assessment. For the sake of 
reproducibility of the method, this constant needed to be estimated, even if in a partly subjective way (see also Sect. 4.1). Should a lake situated upstream exceed the calculated critical lake area, then it is necessary to assess the susceptibility of this lake to an outburst flood separately (whole procedure). The potential for Scenario 2 of the assessed downstream situated lake is then equal to this result (Fig. 2).

\subsubsection{Potential for dam failure resulting from fast slope movement into the lake (Scenario 3)}

As it was mentioned in the introduction, an assessment of the potential for Scenario 3 requires the same procedure as the assessment of the potential for Scenario 1, with the difference being that the dam erodibility has to be taken into consideration. This term is used to describe the "immunity" of a moraine dam (its outflow) to the extreme flow rate resulting from a displacement wave overtopping a moraine crest.

Therefore, three components need to be incorporated (Table 1): (a) potential for fast slope movement into the lake, (b) potential for dam overtopping by a displacement wave and (c) dam erodibility. The overall potential for Scenario 3 is calculated as a product of these three components and the overall procedure is shown in detail in Fig. 3. The procedure for estimating the components (a) and (b) is similar to the one described in the first scenario (Fig. 1).

For estimating dam erodibility (third component) on the basis of remotely sensed high-resolution images and digital terrain model (DTM) or topographical maps, without any field survey, it is generally necessary to include the characteristics describing dam material, dam geometry and peak discharge. With reduced demands on input data, the dam material is only characterised by dam type (moraine-dammed lake or bedrock-dammed lake). Dam geometry is represented by the maximum slope of the distal face of the dam $\left(S_{\text {DFDmax }}\right.$; see below) and peak discharge is calculated in the form of a peak discharge factor $\left(P_{\mathrm{DF}}\right)$. The calculation of the peak discharge factor is different for the different scenarios. Therefore, $P_{\mathrm{DFS} 3}$ is used for Scenario 3, while $P_{\mathrm{DFS} 4}$ is used in Scenario 4 (see Sect. 2.3.4; Eq. 11).

The presented method does not quantify the volume of potential slope movement(s) into the lake, thus $P_{\mathrm{DFS} 3}$ is designed to simplistically describe the peak discharge for an idealised unitary fast slope movement into the lake. In this scenario, $P_{\mathrm{DFS} 3}$ is calculated as follows:

$$
P_{\mathrm{DFS} 3}=1-r_{D_{\mathrm{f}} / V}
$$

where $r_{D_{\mathrm{f}} / V}$ is the ratio of the dam freeboard to the cube root of the lake volume ( $r_{D_{\mathrm{f}} / V}=$ (unitless); Eq. 5). After that, erodibility of the dam for Scenario $3\left(E_{\mathrm{RDBS} 3}\right)$ is estimated as follows:

$$
E_{\mathrm{RDBS} 3}=\sin \left(S_{\mathrm{DFDmax}}\right) \cdot P_{\mathrm{DFS} 3},
$$

where $S_{\text {DFDmax }}$ is the maximum slope of the distal face of the dam $\left(S_{\text {DFDmax }}=\left(^{\circ}\right)\right)$, simplistically describing the dam geometry and thus susceptibility to erosion (erodibility). The maximum slope of the distal face of the moraine was used to capture the most vulnerable part of the moraine dam as we suppose that this is more predicative than the use of the mean slope (in contrary to methods presented by Wang et al., 2008, 2011; Mergilli and Schneider, 2011). Without the need for field survey, we can assume a uniform internal composition of different moraine dams. $P_{\mathrm{DFS} 3}$ is the peak discharge factor for Scenario 3 ( $P_{\mathrm{DFS} 3}=$ (unitless); Eq. 9). Therefore the erodibility of the dam in the presented method is only dependent on (a) the maximum slope of the distal face of the dam and (b) the peak discharge factor.

\subsubsection{Potential for dam failure following a flood wave originating in a lake situated upstream (Scenario 4)}

It is generally necessary to take three components into account for a meaningful assessment of the potential for the Scenario 4 (see Table 1). These are (a) retention potential of a lake situated downstream (assessed lake), (b) potential for a flood wave from a lake situated upstream and (c) dam erodibility of a downstream situated (assessed) lake. The overall procedure (decision tree) for assessing the potential for Scenario 4 is described in Fig. 4. The procedure for the estimation of components (a) and (b) is similar to the one described in the Scenario 2 (see Sect. 2.3.2; Fig. 2).

Analogically to the previous scenario, dam failure may only occur in the case of moraine-dammed lakes. Therefore, the first step in assessing the potential for Scenario 4 is to distinguish between the different dam types (Fig. 4). The peak discharge factor for Scenario 4 (dam failure following a flood wave originating in a lake situated upstream) is calculated as follows:

$P_{\mathrm{DFS} 4}=\left(\left(V-V_{\text {ret }}\right) / A\right)^{2}$,

where $V$ is the volume of the lake situated upstream $\left(V=\left(\mathrm{m}^{3}\right)\right.$; Eq. 4), $V_{\text {ret }}$ is the retention potential of a downstream situated (assessed) lake $\left(V_{\text {ret }}=\left(\mathrm{m}^{3}\right)\right.$; Eq. 6) and $A$ is the area of the assessed lake $\left(A=\left(\mathrm{m}^{2}\right)\right)$. The peak discharge factor $\left(P_{\mathrm{DFS} 4}=\left(\mathrm{m}^{2}\right)\right)$ is designed to substitute the peak discharge, which can be generally expressed as a product of the cross-sectional area and flow velocity. The flow velocity is not known, thus $P_{\mathrm{DFS} 4}$ is based only on the cross-sectional area of the flow. The power of two was used to stress that the cross-sectional area and the peak discharge increase exponentially with an increase in the water level, which is expressed as $\left(V-V_{\text {ret }} / A ;(\mathrm{m})\right)$. If $P_{\mathrm{DFS} 4}>1, P_{\mathrm{DFS} 4}=1$ is used in the following calculation of dam erodibility for Scenario 4 $\left(E_{\mathrm{RDBS} 4}=(\right.$ unitless $\left.)\right)$ :

$E_{\mathrm{RDBS} 4}=\sin \left(S_{\mathrm{DFDmax}}\right) \cdot P_{\mathrm{DFS} 4}$,

where $S_{\text {DFDmax }}$ is the maximum slope of the distal face of the dam $\left(S_{\mathrm{DFDmax}}=\left(^{\circ}\right)\right)$, and $P_{\mathrm{DFS} 4}$ is the peak discharge factor for Scenario $4\left(P_{\mathrm{DFS} 4}=(\right.$ unitless $)$; Eq. 11). Analogically 


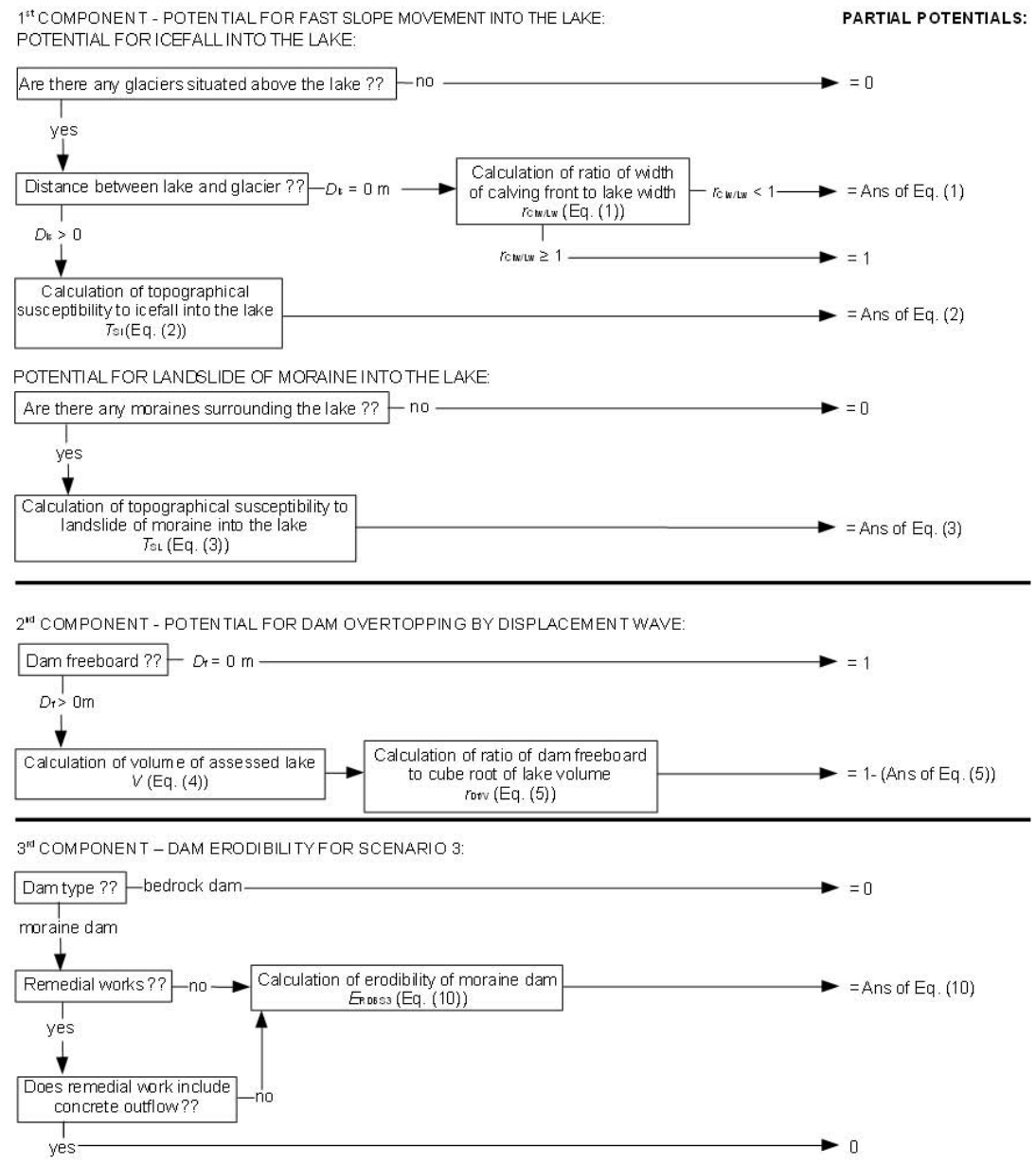

Figure 3. Decision tree for assessing the potential for dam failure resulting from a fast slope movement into the lake (Scenario 3 ). The overall potential is derived as a product of three partial components.

to Scenario 2, in the presented method we assume a gradual increase in the water level in the downstream situated lake rather than the formation of the significant displacement wave. The retention potential of the valley between the consecutive lakes is also not considered.

\subsubsection{Potential for dam failure following a strong earthquake (Scenario 5)}

An assessment of the potential for Scenario 5 requires two components to be included (see Table 1). These are (a) potential for a strong earthquake and (b) dam instability. The Cordillera Blanca is generally considered to be one of the seismically most active high-mountain regions of the contemporary world. It is clear that the potential for a strong earthquake in comparison with other regions of the world needs deeper evaluation; on the other hand, the potential for a strong earthquake on a regional scale (assessing the differences between each parts of this mountain range) is not needed. A South American seismic hazard map presented by USGS (Giardini et al., 1999; Rhea et al., 2010) shows that whole region of the Cordillera Blanca is categorised as a zone with maximum peak ground acceleration (PGA) of between 3.2 to $6.4 \mathrm{~m} \mathrm{~s}^{-2}$. Although most earthquakes have their origin in the subduction zone of the Pacific Ocean, we suppose that there is no significant difference in the maximum PGA between the west and east side of the Cordillera Blanca. Therefore, the whole region of the Cordillera Blanca has an equivalent (similar) potential for strong earthquakes, and it is not necessary to take characteristics of potential earthquakes into account on a regional scale during the assessment of the susceptibility of glacial lakes to outburst floods in the presented method. Thus, the first component in the assessment of the potential for dam failure following a strong earthquake (potential for strong earthquake) is always equal to 1 (the whole region is susceptible to a strong earthquake).

The second component (dam instability) firstly requires an assessment of dam type. It is clear that dam failure following a strong earthquake is not a possible scenario for bedrock-dammed lakes, because bedrock dams are generally considered to be stable (dam instability $=0$ and overall 


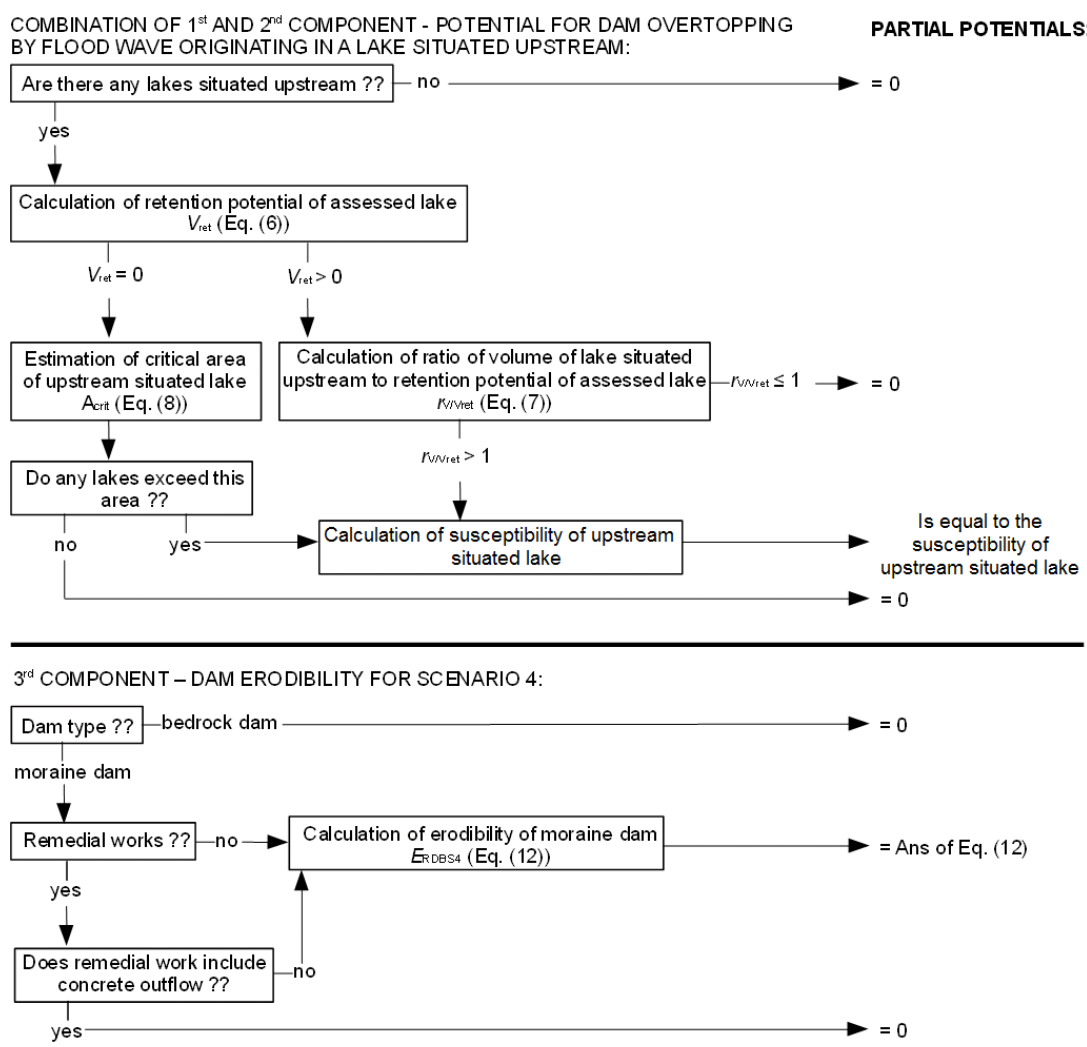

Figure 4. Decision tree for assessing the potential for dam failure following a flood wave originating in a lake situated upstream (Scenario 4). The overall potential is derived as a product of three partial components.

potential for dam failure following a strong earthquake $=0$; see Fig. 5).

It has been shown that moraine dam failure following a strong earthquake occurs due to changes in the internal structure of the dam and consequent internal erosion (piping), which cyclically increases its rate due to the increasing discharge (positive feedback mechanism; Lliboutry et al., 1977; Yamada, 1998). In extreme cases, increasing piping may lead to dam rupture. Therefore, a crucial characteristic in assessing the potential for dam failure following a strong earthquake is information about the internal structure of the dam, represented in this study by piping through the dam. If piping occurs, the estimation of dam instability $\left(D_{\mathrm{I}}=\right.$ (unitless)) requires the following procedure, which starts with a calculation of the ratio between the dam height and the dam width $\left(r_{D_{\mathrm{h}} / D_{\mathrm{w}}}=(\right.$ unitless $\left.)\right)$ as follows:

$r_{D_{\mathrm{h}} / D_{\mathrm{w}}}=D_{\mathrm{h}} / D_{\mathrm{w}}$

where $D_{\mathrm{h}}$ is dam height $\left(D_{\mathrm{h}}=(\mathrm{m})\right), D_{\mathrm{w}}$ is dam width $\left(D_{\mathrm{w}}=(\mathrm{m})\right)$. Then, dam instability $\left(D_{\mathrm{I}}=(\right.$ unitless $\left.)\right)$ is calculated as follows:

$D_{\mathrm{I}}=r_{D_{\mathrm{h}} / D_{\mathrm{w}}} \cdot \sin (2 \gamma)$,

where $r_{D_{\mathrm{h}} / D_{\mathrm{w}}}$ is the ratio between the dam height and the dam width $\left(r_{D_{\mathrm{h}} / D_{\mathrm{w}}}=\right.$ (unitless); Eq. 13), and $\gamma$ is the piping gradient $\left(\gamma=\left(^{\circ}\right)\right)$. The piping gradient provides information about the slope between the lake water level and piping springs. A double value is used to emphasise the role of $\gamma$, which is rarely higher than $20^{\circ}$. In the case that there is no evidence of piping, dam instability $\left(D_{\mathrm{I}}=\right.$ (unitless)) is calculated as follows:

$D_{\mathrm{I}}=\left(r_{D_{\mathrm{h}} / D_{\mathrm{w}}}\right)^{2}$,

where $r_{D_{\mathrm{h}} / D_{\mathrm{w}}}$ is the ratio between the dam height and the dam width $\left(r_{D_{\mathrm{h}} / D_{\mathrm{w}}}=\right.$ (unitless); Eq. 13). The power of two of $r_{D_{\mathrm{h}} / D_{\mathrm{w}}}$ was used to emphasise that no piping occurs (to stress dam geometry).

\subsection{Required input data}

The presented method is designed to provide a repeatable methodological concept for assessing the susceptibility of a high number of lakes to outburst floods, with a limited demand on input data. We believe that the method for assessing the susceptibility of glacial lakes to outburst floods and incorporating the assessed characteristics should always be partly subordinated to data availability, in order to provide applicability and repeatability of the method. The presented method focuses on a wide range of users and thus is designed for broadly available input data. All of the assessed characteristics (see Table 2) are easily derivable from high-resolution 


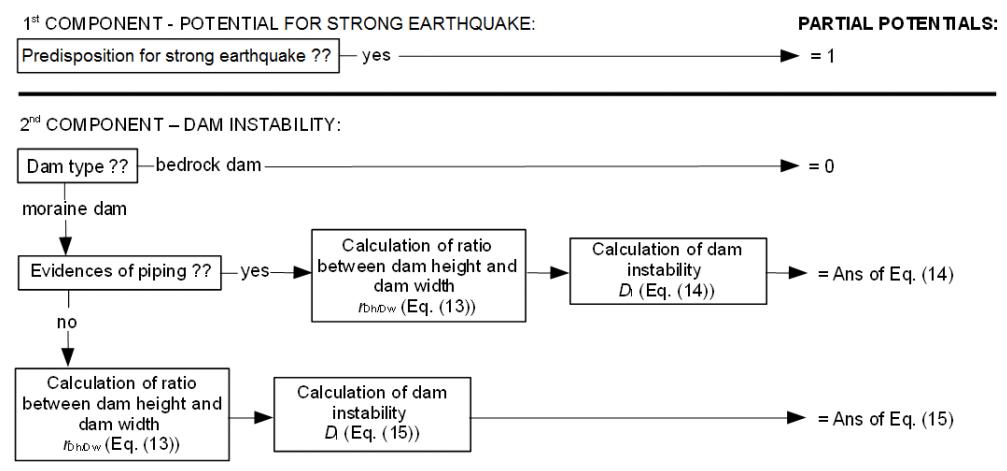

Figure 5. Decision tree for assessing the potential for dam failure following a strong earthquake (Scenario 5).

optical images (e.g. Google Earth Digital Globe, 2014) and digital terrain models (or topographical maps). Characteristics which need field survey (e.g. geological setting, detailed glaciological setting or characteristics describing the internal dam structure such as buried ice presence/absence) are not incorporated.

\section{Method verification}

\subsection{General principle}

It is always highly important to verify the relevance of a new method, to prove its functionality. The main idea of the presented method verification is the assessment of the susceptibility of several lakes to outburst floods, of which some have produced GLOFs since the end of Little Ice Age (Table 3) and some have not. Seven lakes from the region of the Cordillera Blanca, which have produced 10 GLOFs, were selected so that different lake types, different causes and different scenarios of GLOFs are represented. Another criterion was data availability for historical events (scientific publications, aerial photos, reports from ANA archive, Huaráz, Peru). Ten lakes which have not yet produced a GLOF were chosen to be assessed to prove the presented method in comparison with GLOF-producing lakes. These 10 lakes were selected so that different lake types and settings are represented. Therefore, a total number of 20 lakes (pre-flood conditions respectively) were examined.

An assessment of the pre-flood conditions of the lakes which have already produced GLOFs should show whether the presented method allows us to identify the most likely GLOF scenario for a particular lake (comparison with real cause) and if these lakes will have a higher potential than lakes which have not yet produced GLOFs. A comparison between the pre-GLOF conditions of the lakes which have produced GLOFs with those which have not should highlight the most susceptible lakes for each scenario. The assumption is that the presented method should clearly distinguish between lakes which have already produced GLOFs and those which have not.

\subsection{Input data used for method verification}

Input data for assessing the pre-GLOF conditions of the examined events as well as input data for assessing the susceptibility of lakes which have not yet produced GLOFs were gained from various sources: (a) remotely sensed images (Google Earth Digital Globe 2014 covering the Cordillera Blanca region since 1970; three sets of old aerial photographs for the periods 1948-1950, 1962-1963 and 1970); (b) unpublished research reports from the archive of Autoridad National del Agua (Huaráz, Peru); (c) data and information gained during a field survey performed in May/June 2012, June/July 2013 and May/June 2014; (d) contemporary and historical ground-based photos from the studied sites and (e) topographical maps at a scale of $1: 25000$ from the Peruvian cadastral office (COFOPRI) with basic contour intervals of $25 \mathrm{~m}$. A comprehensive list of input data used for the assessment is presented in the Supplement.

\subsection{Results}

The results of the method can generally be verified from two points of view: (a) the most likely scenario for a particular lake and (b) the most susceptible lake for each scenario. A combination of both of these results provides quite a good overview of the susceptibility of the examined lakes to outburst floods.

\subsubsection{The most likely scenario for a particular lake}

Verification of the most likely scenario of a GLOF for particular lake is relevant only in the case of lakes which have already produced GLOFs (seven lakes, 10 examined pre-flood conditions). It is important to stress that the potential for Scenario 1 and Scenario 2 (dam overtopping) is always higher than or equal to the potential for Scenario 3 and Scenario 4, respectively, because dam overtopping is a prerequisite for dam failure. We feel it is relevant to distinguish between these mechanisms of GLOFs because of subsequent flood modelling and an estimation of the volume of potentially released water. 
Table 3. List of examined lakes (historical GLOFs).

\begin{tabular}{|c|c|c|c|c|c|}
\hline Lake & Valley & Date of GLOF & Lake type & Probable scenario & Reference \\
\hline Artesoncocha $(7 / 1951)$ & Parón & 16-17 July 1951 & MDL & $\begin{array}{l}\text { Dam failure following icefall } \\
\text { into the lake }\end{array}$ & $\begin{array}{l}\text { Ghiglino and Spann (1951); } \\
\text { Lliboutry et al. (1977) }\end{array}$ \\
\hline Artesoncocha (10/1951) & Parón & 28 October 1951 & MDL & $\begin{array}{l}\text { Dam failure following icefall } \\
\text { into the lake }\end{array}$ & $\begin{array}{l}\text { Torres and Brottger (1951); } \\
\text { Lliboutry et al. (1977) }\end{array}$ \\
\hline Artizon Alto & Artizon/Santa Cruz & 8 February 2012 & BDL & $\begin{array}{l}\text { Dam overtopping following a } \\
\text { landslide of lateral moraine } \\
\text { into the lake }\end{array}$ & Emmer et al. (2014) \\
\hline Artizon Bajo & Artizon/Santa Cruz & 8 February 2012 & MDL & $\begin{array}{l}\text { Dam failure following a flood } \\
\text { wave from a lake situated } \\
\text { upstream }\end{array}$ & Emmer et al. (2014) \\
\hline Jancarurish & Los Cedros & 20 October 1950 & MDL & $\begin{array}{l}\text { Dam failure following icefall } \\
\text { into the lake }\end{array}$ & Lliboutry et al. (1977) \\
\hline Lake no. 513 & Chucchun & 11 April 2010 & BDL & $\begin{array}{l}\text { Dam overtopping following } \\
\text { ice/rock fall into the lake }\end{array}$ & $\begin{array}{l}\text { Carey et al. (2012), Klimeš } \\
\text { et al. (2014) }\end{array}$ \\
\hline Palcacocha (1941) & Cojup & 13 December 1941 & MDL & $\begin{array}{l}\text { Dam failure following icefall } \\
\text { into the lake }\end{array}$ & Oppenheim (1946) \\
\hline Palcacocha (2003) & Cojup & 19 March 2003 & MDL & $\begin{array}{l}\text { Dam overtopping following a } \\
\text { landslide of lateral moraine } \\
\text { into the lake }\end{array}$ & Vilímek et al. (2005) \\
\hline Safuna Alta (1970) & Tayapampa/Collota & 31 May 1970 & MDL & $\begin{array}{l}\text { Dam failure caused by an } \\
\text { earthquake }\end{array}$ & Lliboutry et al. (1977) \\
\hline Safuna Alta (2002) & Tayapampa/Collota & 22 April 2002 & MDL & $\begin{array}{l}\text { Dam overtopping following a } \\
\text { rockslide/rockfall into the lake }\end{array}$ & Hubbard et al. (2005) \\
\hline
\end{tabular}

BDL: bedrock-dammed lake; MDL: moraine-dammed lake.

Table 4. Pre-GLOF condition (susceptibility to outburst floods) of lakes assessed by the presented method (Bold - the highest potential for a particular lake; italicised - the actual cause).

\begin{tabular}{|c|c|c|c|c|c|c|}
\hline \multirow[b]{2}{*}{ Lake (condition) } & \multirow[b]{2}{*}{$\begin{array}{l}\text { Recorded GLOF trigger } \\
\text { and mechanism }\end{array}$} & \multicolumn{2}{|c|}{ Potential for dam overtopping as a result of } & \multicolumn{3}{|c|}{ Potential for dam failure as a result of } \\
\hline & & $\begin{array}{r}\text { Fast slope } \\
\text { movement into } \\
\text { the lake }(\text { Scenario } 1)\end{array}$ & $\begin{array}{r}\text { Flood wave from } \\
\text { a lake situated } \\
\text { upstream (Scenario 2) }\end{array}$ & $\begin{array}{r}\text { Fast slope } \\
\text { movement into the } \\
\text { lake (Scenario 3) }\end{array}$ & $\begin{array}{r}\text { Flood wave from } \\
\text { a lake situated } \\
\text { upstream (Scenario 4) }\end{array}$ & $\begin{array}{r}\text { Strong earthquake } \\
\text { (Scenario 5) }\end{array}$ \\
\hline Artesoncocha $(7 / 1951)$ & $\begin{array}{l}\text { Dam failure following } \\
\text { icefall into the lake }\end{array}$ & 1.000 (calving) & 0.000 & 0.259 & 0.000 & 0.025 \\
\hline Artesoncocha (10/1951) & $\begin{array}{l}\text { Dam failure following } \\
\text { icefall into the lake }\end{array}$ & 1.000 (calving) & 0.000 & 0.225 & 0.000 & 0.019 \\
\hline Artizon Alto & $\begin{array}{l}\text { Landslide of moraine/dam } \\
\text { overtopping }\end{array}$ & 0.996 (landslide) & 0.000 & 0.000 & 0.000 & 0.000 \\
\hline Artizon Bajo & $\begin{array}{l}\text { Flood wave from a lake } \\
\text { situated upstream/dam } \\
\text { failure }\end{array}$ & 0.985 (landslide) & 0.996 & 0.205 & 0.207 & 0.026 \\
\hline Jancarurish & Icefall/dam failure & 0.983 (calving) & 0.000 & 0.554 & 0.000 & 0.135 \\
\hline Lake no. 513 & Icefall/dam overtopping & 0.378 (icefall) & 0.000 & 0.000 & 0.000 & 0.000 \\
\hline Palcacocha (1941) & Icefall/dam failure & 1.000 (calving) & 0.000 & 0.559 & 0.000 & 0.217 \\
\hline Palcacocha (2003) & $\begin{array}{l}\text { Landslide of moraine/dam } \\
\text { overtopping }\end{array}$ & 0.961 (calving) & 0.000 & 0.000 & 0.000 & 0.026 \\
\hline Safuna Alta (1970) & $\begin{array}{l}\text { Dam failure following } \\
\text { strong earthquake }\end{array}$ & 0.604 (calving) & 0.000 & 0.279 & 0.000 & 0.231 \\
\hline Safuna Alta (2002) & $\begin{array}{l}\text { Landslide of moraine/dam } \\
\text { overtopping }\end{array}$ & 0.589 (landslide) & 0.000 & 0.261 & 0.000 & 0.147 \\
\hline
\end{tabular}

The presented method successfully identified real GLOF triggers in 9 out of 10 cases (the only exception was the Lake Safuna Alta 1970 event; see Table 4). The condition of Lake Safuna Alta before a catastrophic earthquake occurred on the 31 May 1970 indicated that the most likely GLOF scenario was Scenario 1 (dam overtopping by a displacement wave caused by calving of the glacier into the lake). The real cause of the flood was Scenario 5 (earthquake-induced piping). In fact, Lake Safuna Alta was assessed as the lake with the highest potential for Scenario 5 of all of the assessed lakes. From 

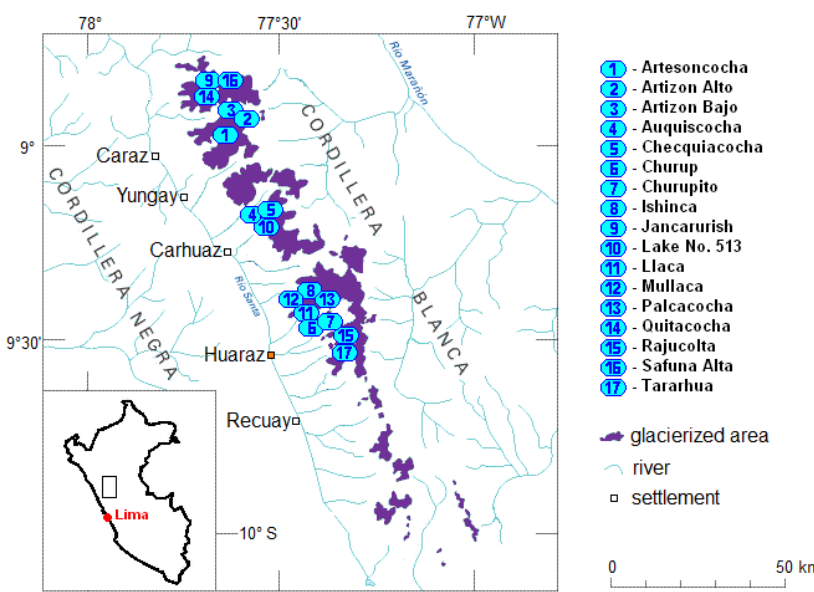

Figure 6. Localisation of studied lakes (base map modified according to USGS).

this point of view, it is also quite important to compare the results within each scenario (see Sect. 3.3.2).

\subsubsection{The most susceptible lake for each scenario}

The results of the assessment of the potential for each scenario were ranked from the highest to the lowest potential for a GLOF (see Table 5). In general, the presented method reliably distinguishes between lakes which later produced GLOFs to those which did not. Detailed results for each scenario are described below.

Scenario 1: it can be clearly seen that the susceptibility to outburst floods of pre-flood conditions of lakes which have produced GLOFs by Scenario 1 reached the seven highest potentials (Fig. 7). Three conditions reached the maximum potential of 1.00. These were the conditions of Lake Artesoncocha, before it produced GLOFs in July and October 1951 and Lake Palcacocha before it produced a GLOF in 1941. Four other lakes which have already produced GLOFs reached a potential for Scenario 1 higher than 0.95. After that, a significant decrease in the reached potentials is evident and lakes which have not yet produced GLOFs are ranked.

The presented method works perfectly until the thirteenth position. After that there are two evident disharmonies - the Lake Safuna Alta 2002 event (14th position) and the Lake no. 5132010 event (20th position). We have the following explanation for this phenomenon: first, both of these events were caused by an extraordinary high-volume slope movement, which cannot be reliably identified or accurately predicted without detailed field glaciological and geological survey. Second, both of these lakes have a dam freeboard of the order of tens of metres, which would help to significantly limit the expected low- or middle-scale events and thus decrease the susceptibility for dam overtopping in the presented method. From another point of view, the large-scale fast slope movement can be characterised as a "quasi-random" event (see

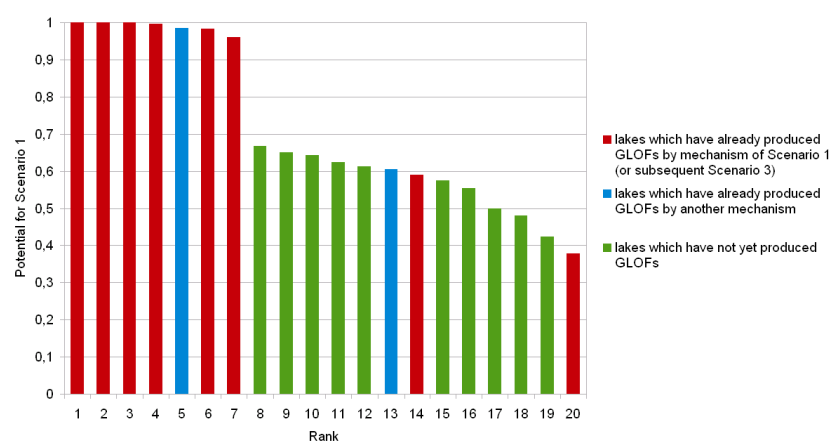

Figure 7. Assessed lakes and their potential for Scenario 1 ranked from the highest to the lowest. The results for particular lakes are listed in Table 5.

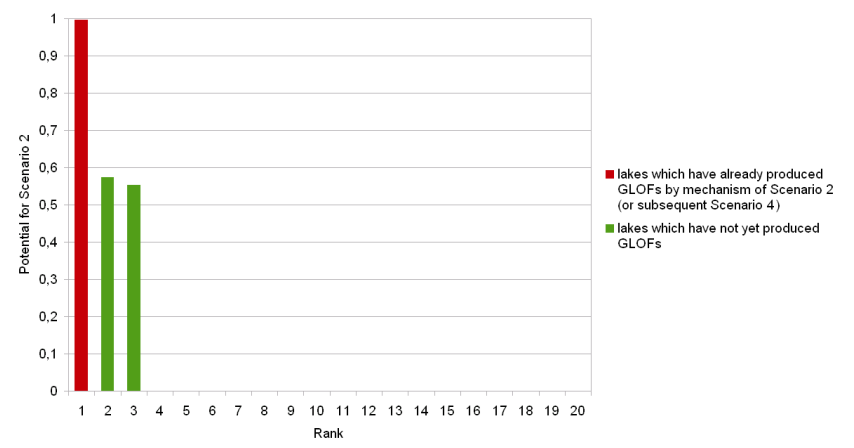

Figure 8. Assessed lakes and their potential for Scenario 2 ranked from the highest to the lowest (please note that the empty columns represent lakes with a zero potential for this scenario; the results for particular lakes are listed in Table 5).

Sect. 4.3) and a GLOF following its potential impact on the affected lake may occur elsewhere, even from an ostensibly safe lake (e.g. Lake no. 513, which was generally considered as safe after the level of the artificial lake decreased by about $20 \mathrm{~m}$; nevertheless, a GLOF occurred in 2010; Carey et al., 2012).

Scenario 2: the presented method reliably identified the only event that involved Scenario 2 (Fig. 8). This was dam overtopping and subsequent dam failure of Lake Atizon Bajo following a flood wave from Lake Artizon Alto in 2012 (potential 0.996). Two other lakes have significantly large lakes situated upstream in their catchment area, and thus have a nonzero potential for Scenario 2 (Churup and the upstream situated Lake Churupito; Auquiscocha and the upstream situated Lake Checquiacocha). Neither of these systems have produced a GLOF and this was confirmed by them reaching significantly lower potentials (0.574 and 0.553 , respectively) in comparison with the Atizon cascade. On the other hand, the low number of the examined events of this scenario is a potential shortcoming, with the Artizon 2012 event being the only well-documented event of Scenario 2 (Scenario 4, respectively) from the Cordillera Blanca region. 
Table 5. Results of the assessment of the susceptibility of the examined lakes (and pre-floods conditions) ranked from the highest to the lowest for each scenario (Bold - non-zero results; please note that the zero results are listed alphabetically).

\begin{tabular}{|c|c|c|c|c|c|c|c|c|c|c|}
\hline \multirow{2}{*}{ Rank } & \multicolumn{2}{|l|}{ Scenario 1} & \multicolumn{2}{|l|}{ Scenario 2} & \multicolumn{2}{|l|}{ Scenario 3} & \multicolumn{2}{|l|}{ Scenario 4} & \multicolumn{2}{|l|}{ Scenario 5} \\
\hline & Lake (condition) & Result & Lake (condition) & Result & Lake (condition) & Result & Lake (condition) & Result & Lake (condition) & Result \\
\hline 1. & Artesoncocha (7/1951) & 1.000 & Artizon Bajo & 0.996 & Palcacocha (1941) & 0.559 & Artizon Bajo & 0.207 & Safuna Alta (1970) & 0.231 \\
\hline 2. & Artesoncocha (10/1951) & 1.000 & Auquiscocha & 0.574 & Jancarurish & 0.554 & Artesoncocha (7/1951) & 0.000 & Palcacocha (1941) & 0.217 \\
\hline 3. & Palcacocha (1941) & 1.000 & Churup & 0.553 & Safuna Alta (1970) & 0.279 & Artesoncocha (10/1951) & 0.000 & Safuna Alta (2003) & 0.147 \\
\hline 4. & Artizon Alto & 0.996 & Artesoncocha (7/1951) & 0.000 & Safuna Alta (2002) & 0.261 & Artizon Alto & 0.000 & Churupito & 0.147 \\
\hline 5. & Artizon Bajo & 0.985 & Artesoncocha (10/1951) & 0.000 & Quitacocha & 0.261 & Auquiscocha & 0.000 & Mullaca & 0.147 \\
\hline 6. & Jancarurish & 0.983 & Artizon Alto & 0.000 & Artesoncocha (7/1951) & 0.259 & Checquiacocha & 0.000 & Jancarurish & 0.135 \\
\hline 7. & Palcacocha (2003) & 0.961 & Checquiacocha & 0.000 & Checquiacocha & 0.243 & Churup & 0.000 & Quitacocha & 0.122 \\
\hline 8. & Rajucolta & 0.668 & Churupito & 0.000 & Artesoncocha (10/1951) & 0.225 & Churupito & 0.000 & Llaca & 0.072 \\
\hline 9. & Llaca & 0.651 & Ishinca & 0.000 & Churupito & 0.225 & Ishinca & 0.000 & Ishinca & 0.067 \\
\hline 10. & Tararhua & 0.643 & Jancarurish & 0.000 & Artizon Bajo & 0.205 & Jancarurish & 0.000 & Checquiacocha & 0.034 \\
\hline 11. & Quitacocha & 0.624 & Lake no. 513 & 0.000 & Tararhua & 0.089 & Lake no. 513 & 0.000 & Artizon Bajo & 0.026 \\
\hline 12. & Ishinca & 0.612 & Llaca & 0.000 & Artizon Alto & 0.000 & Llaca & 0.000 & Palcacocha (2003) & 0.026 \\
\hline 13. & Safuna Alta (1970) & 0.604 & Mullaca & 0.000 & Auquiscocha & 0.000 & Mullaca & 0.000 & Artesoncocha (7/1951) & 0.025 \\
\hline 14. & Safuna Alta (2002) & 0.589 & Palcacocha (1941) & 0.000 & Churup & 0.000 & Palcacocha (1941) & 0.000 & Rajucolta & 0.025 \\
\hline 15. & Checquiacocha & 0.574 & Palcacocha (2003) & 0.000 & Ishinca & 0.000 & Palcacocha (2003) & 0.000 & Artesoncocha (10/1951) & 0.019 \\
\hline 16. & Churupito & 0.553 & Quitacocha & 0.000 & Lake no. 513 & 0.000 & Quitacocha & 0.000 & Tararhua & 0.016 \\
\hline 17. & Auquiscocha & 0.500 & Rajucolta & 0.000 & Llaca & 0.000 & Rajucolta & 0.000 & Artizon Alto & 0.000 \\
\hline 18. & Mullaca & 0.48 & Safuna Alta (1970) & 0.000 & Mullaca & 0.000 & Safuna Alta (1970) & 0.000 & Auquiscocha & 0.000 \\
\hline 19. & Churup & 0.423 & Safuna Alta (2002) & 0.000 & Palcacocha (2003) & 0.000 & Safuna Alta (2002) & 0.000 & Churup & 0.000 \\
\hline 20. & Lake no. 513 & 0.378 & Tararhua & 0.000 & Rajucolta & 0.000 & Tararhua & 0.000 & Lake no. 513 & 0.000 \\
\hline
\end{tabular}

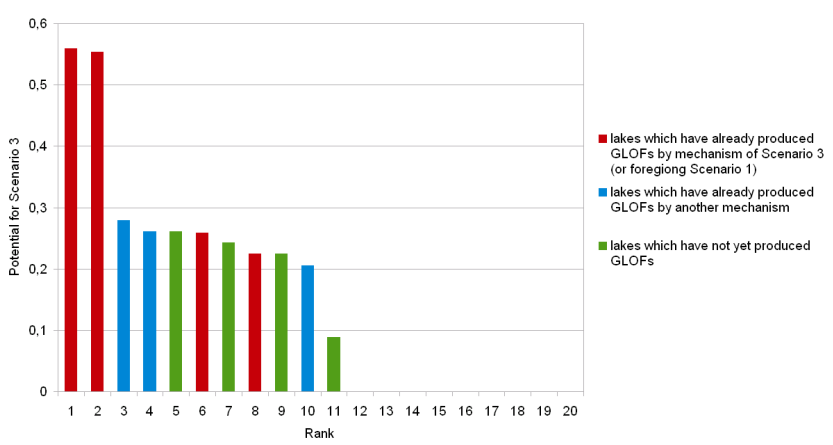

Figure 9. Assessed lakes and their potential for Scenario 3 ranked from the highest to the lowest (please note that the empty columns represent lakes with a zero potential for this scenario; the results for particular lakes are listed in Table 5).

Scenario 3: the results of the potential for dam failure following fast slope movement into the lake reliably identified the dam failures of Lake Palcacocha in 1941 (potential 0.559) and Lake Jancarurish in 1951 (potential 0.554; see Fig. 9). The remaining two dam failures of Lake Artesoncocha reached a substantially lower potential $(0.259$ and $0.225)$ than the potentials reached by lakes which have not produced GLOFs yet (Quitacocha, Checquiacocha). We interpret these lakes as being susceptible to dam failure following fast slope movement into the lake. It is important to realise that dam erodibility (a component of this scenario) is quite a complex issue, which is always estimated with a degree of uncertainty and approximation when the assessment is based on remotely sensed photos and DTMs (topographical maps) without any field survey. If we take this fact into the account then the provided results are quite representative.

Scenario 4: our investigation showed that the only lake susceptible to Scenario 4 is Lake Artizon Bajo (its pre-flood

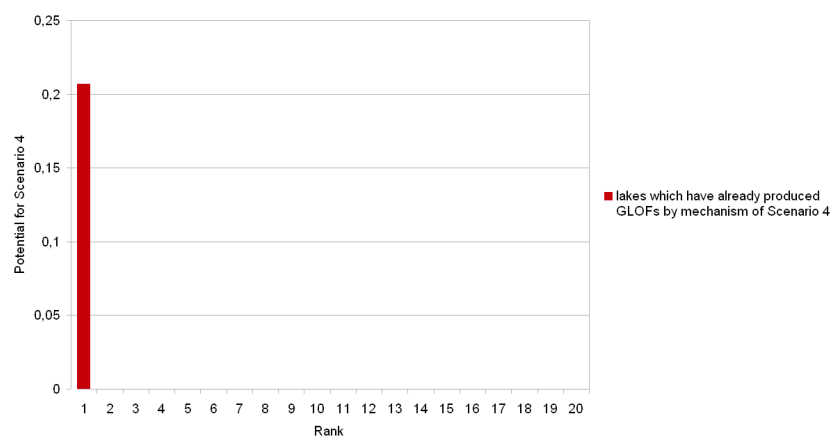

Figure 10. Assessed lakes and their potential for Scenario 4 ranked from the highest to the lowest (please note that empty columns represent lakes with a zero potential for this scenario; the results for particular lakes are listed in Table 5).

condition) with a potential of 0.207 (Fig. 10). This lake produced a GLOF in this way in 2012. No other lake from the examined lakes is susceptible to this scenario (there are no lakes significant in size situated upstream of the assessed morainedammed lakes). The presented method reliably identifies the lake susceptible to outburst floods in this case. As in the case of Scenario 2, the low number of examined events (dam failures following this mechanism) has to be considered, with the Artizon 2012 event being the only well-documented event of Scenario 4 from the Cordillera Blanca region.

Scenario 5: lake with a higher potential for Scenario 5 was also identified successfully (Fig. 11). The only case of this scenario from the examined events (piping of Lake Safuna Alta after a strong earthquake in 1970) reached the highest potential of 0.231 , followed by the condition of Lake Palcacocha before the 1941 outburst with a potential of 0.217. Afterwards there was a significant decrease in potential, with the third position being occupied by the pre-flood condition 


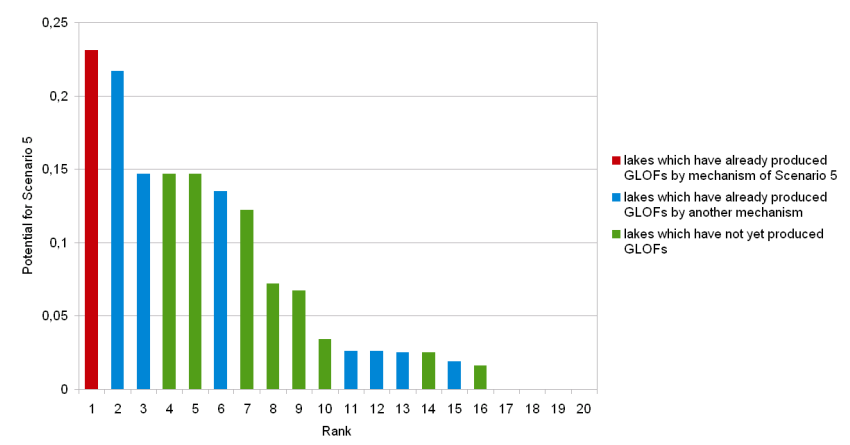

Figure 11. Assessed lakes and their potential for Scenario 5 ranked from the highest to the lowest (please note that the empty columns represent lakes with a zero potential for this scenario; the results for particular lakes are listed in Table 5).

of the Safuna Alta 2003 event as well as lakes Churupito and Mullaca.

\subsubsection{Lakes susceptible to outburst floods}

Based on a comparison of the results obtained from the assessment of susceptibility of 10 pre-flood conditions of lakes which have already produced GLOFs and 10 conditions of lakes which have not yet produced GLOFs, we recommend interpreting "lakes susceptible to outburst flood" as lakes which reach more than 0.9 in Scenario 1, more than 0.5 in Scenario 3; or more than 0.2 in Scenario 5. In the case of Scenarios 2 and 4, we recommend using the above-mentioned values depending on the most likely scenario of a GLOF originating from an upstream situated lake. The relatively low number of examined events should also be taken into consideration.

\section{Discussion}

\subsection{Method construction, decision trees and calculations}

In order to provide an easily repeatable and reproducible methodological concept for assessing the susceptibility of a greater number of glacial lakes to outburst floods without the need for field survey (based on remotely sensed data, DTMs and/or topographical maps), it was necessary to provide a clear and instructive guide (represented by decision trees), where all of the thresholds are defined and thus the room for doubt during assessment is limited as much as possible. Therefore, it is clear that some simplifications needed to be done. These simplifications are connected especially to the schematic description of the GLOF mechanisms (scenarios); on the other hand, all of these scenarios have previously been described from the study area and they are not artificial. Also, several of the equations used in the calculations are schematic or simplified (e.g. Eqs. 10, 11, 14) due in particular to the limited demand on input data (assumption of repeatability and reproducibility). In addition some thresholds needed to be estimated artificially and partly subjectively, based on expert experience and opinion (e.g. constant 0.05 in Eq. 8). In these cases, more detailed investigation for more precise estimation of these thresholds should be performed in the future (see the recommendation for the future research in Sect. 5). Manual assessment of certain characteristics such as dam type is also needed in the presented method (see also method limitations in Sect. 4.4).

\subsection{Interpretation of results}

It is highly important not to misinterpret the obtained results with regard to the character of the presented method. Therefore, we would like to emphasise that the presented method provides information about the susceptibility of a particular glacial lake to outburst floods. Potentials for five different scenarios of GLOFs, which have been previously recorded in the studied region, are assessed. On the other hand, the presented method does not reflect any other possible GLOF scenario (e.g. dam failure following melting of buried ice reported from mountain ranges of Central Asia; Ives et al., 2010; Richardson and Reynolds, 2000b). The presented method also does not take into account the magnitude of potential outburst floods (as well as, for example, the volume of potential fast slope movement into the lake) or downstream impacts (downstream hazard assessment).

\subsection{Potential sources of errors}

It is not possible to exactly predict the behaviour of the complex Earth system with the current state of knowledge and analogically the occurrence of GLOFs cannot be exactly predicted because this question is also highly complex. We are able to modify the spatial component or time component of the assessment but we are not able to refine both of these components simultaneously. This fact is connected with the so-called "quasi-randomness" of the triggering events, e.g. spatio-temporal occurrence and magnitude of fast slope movements, spatio-temporal occurrence and magnitude of earthquakes and occurrence of extreme weather (O'Connor et al., 2001). The quasi-randomness and complexity of GLOF occurrence thus limit the reliability of each method, including the presented one, and represent a potential source of errors. On the other hand, modification of all of the existing approaches and particular methods for use on a regional scale is an attractive scientific challenge. Beside the quasi-randomness and partial unpredictability of the complex Earth system behaviour, potential sources of errors are especially connected to the acquisition and interpretation of input data. Therefore, we recommend using comprehensive and uniform input data, if possible. 


\subsection{Potentials and limitations of the presented method}

In comparison with existing methods for assessing susceptibility of glacial lakes to outburst floods, we feel that the potentials of the presented method are as follows:

a. repeatability, which allows both retrograde, present and also near-future assessment of the susceptibility of glacial lakes to outburst floods and their evolution in time;

b. reproducibility, which allows different observers to gain equal results using the same input data;

c. the principle of multiple results, which allows the most likely GLOF scenario for each lake to be identified and allows characteristics which do not play a role in a specific case to be omitted (scenarios, decision trees).

On the other hand, the presented method also has certain limitations, which mainly result from the type of construction of the method (see Sect. 4.1). These are

a. a compromise between the demands on input data on the one hand and repeatability, reproducibility and the relevance of the obtained results on the other hand;

b. the need for a partial manual assessment (especially for qualitative discrete characteristics such as a distinction between different types of dams, identification of evidence of piping or type of remedial work)

c. time-consuming acquisition of input data for a higher number of assessed lakes (17 characteristics needed for each lake).

\subsection{Applicability in other regions}

The presented method only takes into account the causes and mechanisms of GLOFs recorded within the Cordillera Blanca of Peru and was also verified on the lakes (events) of this mountain range. From this point of view, the presented method is characterised as being regionally focused; nevertheless, the procedure of method verification is generally transferable to other high-mountain regions worldwide. For use in other regions, we recommend verifying the method based on an analysis of the previous events (GLOFs) recorded in the given region and potentially re-evaluating the thresholds determining the susceptibility of the lakes to outburst floods.

\section{Conclusions and future work}

Glacial lake outburst floods (GLOFs) are highly important fluvial-gravitational processes, which represent a significant threat to the inhabitants of the Cordillera Blanca region, Peru. In these days of global climate change and subsequent glacier retreat, the threat of GLOFs is actually increasing. Reliable identification of the threat and assessment of the susceptibility of glacial lakes to outburst floods is a necessary step in risk management and is a basic precondition for the application of effective mitigation tools. In this paper, a new and easily repeatable method for assessing the susceptibility of glacial lakes to outburst floods within the Cordillera Blanca region is presented. In contrast with existing methods, this regionally focused method is based on an assessment of five separate potentials for five different GLOF scenarios, which have been recorded in the studied region. Assessment of preGLOF conditions of lakes which have produced GLOFs in the past and a comparison of these results with an assessment of lakes which have not produced GLOFs yet showed that this method has great potential for identifying the most likely GLOF scenario for a particular lake and also for identifying the most susceptible lake(s) within a group of lakes for each scenario. A distinction between lakes which have already produced GLOFs from those which have not was successful in all five scenarios. We believe that the presented method will serve as an integrated methodological concept for repeated assessment of the susceptibility of glacial lakes to outburst floods within the Cordillera Blanca region.

For future work we especially recommend:

a. a more detailed investigation for more precise specification of thresholds and calculations, based on an analysis of previous GLOFs as well as a field survey (geophysical measurements for estimating the stability of moraine slopes, measurements elucidating the internal structure of moraine dams, etc.);

b. extension of the method for all types of high-mountain lakes (especially for the landslide-dammed lakes which have reached significant volumes in the studied region);

c. an inventory and semi-automatic assessment of the susceptibility of lakes of a significant size within the Cordillera Blanca region to outburst floods, based on the usage of GIS;

d. flood modelling for the lakes with the highest susceptibility to outburst floods, delimitation of potentially affected areas downstream;

e. implementation of effective outburst floods hazard (risk) management tools (both active and passive mitigation measures).

The Supplement related to this article is available online at doi:10.5194/hess-18-3461-2014-supplement. 
Acknowledgements. We would like to especially thank Marco L. Zapata, Alejo Cochachin and the staff of the Autoridad Nacional del Agua (ANA; Huaráz, Peru) for their kind scientific and logistical support during our field survey realised in 2012, 2013 and 2014. We thank Martin Mergili and two anonymous reviewers for their highly constructive and useful comments and suggestions, which significantly helped to improve this work. We also thank Thom Bogaard for processing this manuscript and Craig Hampson BSc (Hons) for language revision. Last but not least we would like to thank the Grant Agency of Charles University (GAUK project no. 70 413) and the Grant Agency of the Czech Republic (GACR project P 209/11/1000) for their financial support.

Edited by: T. Bogaard

\section{References}

Ames, A. M. and Francou, B.: Cordillera Blanca - glaciares en la historia, Bull. Inst. fr. Études andines, 24, 37-64, 1995.

Awal, R., Nakagawa, H., Fujita, M., Kawaike, K., Baba, Y., and Zhang, H.: Experimental study on glacial lake outburst floods due to waves overtopping and erosion of moraine dam, Ann. Disaster Prevention Res. Institute, 53, 583-594, 2010.

Benn, D. I., Bolch, T., Hands, K., Gulley, J., Luckman, A., Nicholson, L. I., Quincey, D., Thompson, S., Toumi, R., and Wiesman, S.: Response of debris-covered glaciers in the Mount Everest region to recent warming,and implications for outburst flood hazards, Earth-Sci. Rev., 114, 156-174, doi:10.1016/j.earscirev.2012.03.008, 2012.

Breien, H., De Blasio, F. V., Elverhøi, A., and Høeg, K.: Erosion and morphology of a debris flow caused by a glacial lake outburst flood, Western Norway, Landslides, 5, 271-280, doi:10.1007/s10346-008-0118-3, 2008.

Bolch, T., Peters, J., Yerogov, A., Pradhan, B., Buchroithner, M., and Blagoveshchensky, V.: Identification of potentially dangerous glacial lakes in the northern Tien Shan, Nat. Hazards, 59, 1691-1714, doi:10.1007/s11069-011-9860-2, 2011.

Carey, M.: Living and dying with glaciers: people's historical vulnerability to avalanches and outburst floods in Peru, Global Planet. Change, 47, 122-134, doi:10.1016/j.gloplacha.2004.10.007, 2005.

Carey, M., Huggel, C., Bury, J., Portocarrero, C., and Haeberli, W.: An integrated socio-environmental framework for glacial hazard management and climate change adaptation: lessons from Lake 513, Cordillera Blanca, Peru, Clim. Change, 112, 733-767, doi:10.1007/s10584-011-0249-8, 2012.

Cenderelli, D. A. and Wohl, E. E.: Peak discharge estimates of glacial-lake outburst floods and "normal" climatic floods in the Mount Everest region, Nepal, Geomorphology, 40, 57-90, doi:10.1016/S0169-555X(01)00037-X, 2001.

Chen, C., Wang, T., Zhang, Z., and Liu, Z.: Glacial Lake Outburst Floods in Upper Nainchu River Basin, Tibet, J. Cold Reg. Eng., 13, 199-212, doi:10.1061/(ASCE)0887-381X(1999)13:4(199), 1999.

Clague, J. J. and Evans, S. G.: A review of catastrophic drainage of moraine-dammed lakes in British Columbia, Quaternary Sci. Rev., 19, 1763-1783, doi:10.1016/S0277-3791(00)00090-1, 2000 .
Clague, J. J., Huggel, C., Korup, O., and McGuire, B.: Climate Change and Hazardous Processes in High Mountains, Rev. Asociación Geol. Argentina, 69, 328-338, 2012.

Cochachin, A. R. and Torres, L. A. (Eds.): Memoria anual 2011: Estudio y monitoreo de lagunas, Autoridad nacional del agua, Unidad de glaciología y recursos hídricos, Huaráz, Peru, 150 pp., 2011.

Cochachin, A. R., Gómez, O. D. V., and Torres, L. A. (Eds.): Memoria anual 2010: Estudio y monitoreo de lagunas, Autoridad nacional del agua, Unidad de glaciología y recursos hídricos, Huaráz, Peru, 153 pp., 2010.

Costa, J. E. and Schuster, R. L.: The formation and failure of natural dams, Geol. Soc. Am. Bull., 100, 1054-1068, doi:10.1130/00167606(1988) 100<1054:TFAFON>2.3.CO;2, 1988.

Emmer, A. and Cochachin, A.: The causes and mechanisms of moraine-dammed lake failures in the Cordillera Blanca, North American Cordillera, and Himalaya, Acta Universitatis Carolinae, Geographica, 48, 5-15, 2013.

Emmer, A. and Vilímek, V.: Review Article: Lake and breach hazard assessment for moraine-dammed lakes: an example from the Cordillera Blanca (Peru), Nat. Hazards Earth Syst. Sci., 13, 1551-1565, doi:10.5194/nhess-13-1551-2013, 2013.

Emmer, A., Vilímek, V., Klimeš, J., and Cochachin, A.: Glacier Retreat, Lakes Development and Associated Natural Hazards in Cordillera Blanca, Peru, in: Landslides in Cold Regions in the Context of Climate Change, Environmental Science and Engineering, Springer, Switzerland, 231-252, 2014.

Evans, S. G. and Clague, J. J.: Recent climatic change and catastrophic geomorphic processes in mountain environments, Geomorphology, 10, 107-128, doi:10.1016/0169-555X(94)90011-6, 1994.

Ghiglino, L. and Spann, H.: Ruptura de la laguna Artesoncocha, Hidroelectra, Lima, 5 pp., 1951.

Giardini, D., Grünthal, G., Shedlock, K., and Zhang, P.: Global seismic hazard map, Annali Geofis., 42, 1225-1230, 1999.

Google Earth Digital Globe: version 7.1.2.2041, Google Inc, available online: server kh.google.com, 2014.

Grabs, W. E. and Hanisch, J.: Objectives and prevention methods for glacier lake outburst floods (GLOFs), in: Snow and Glacier Hydrology (Proceedings of the Kathmandu Symposium, November 1992), IAHS, Great Yarmouth, 341-352, 1993.

Gruber, F. E. and Mergili, M.: Regional-scale analysis of highmountain multi-hazard and risk indicators in the Pamir (Tajikistan) with GRASS GIS, Nat. Hazards Earth Syst. Sci., 13, 27792796, doi:10.5194/nhess-13-2779-2013, 2013.

Hewitt, K.: Natural dams and outburst floods of the Karakoram Himalaya, in: Hydrological Aspects of Alpine and High Mountain Areas, edited by: Glen, J. W., 259-269, 1982.

Hubbard, B., Heald, A., Reynolds, J. M., Quincey, D., Richardson, S. D., Zapata, M. L., Santillán, N. P., and Hambrey, M. J.: Impact of a rock avalanche on a moraine-dammed proglacial lake: Laguna Safuna Alta, Cordillera Blanca, Peru, Earth Surf. Process. Landforms, 30, 1251-1264, doi:10.1002/esp.1198, 2005.

Huggel, C., Kääb, A., Haeberli, W., Teysseire, P., and Paul, F.: Remote sensing based assessment of hazards from glacier lake outbursts: a case study in the Swiss Alps, Can. Geotech. J., 39, 316330, doi:10.1139/T01-099, 2002. 
Huggel, C., Kääb, A., Haeberli, W., Teysseire, P., and Paul, F.: An assessment procedure for glacial hazards in the Swiss Alps, Can. Geotech. J., 41, 1068-1083, doi:10.1139/T04-053, 2004.

Iribarren, A. P., Mackintosh, A., and Norton, K. P.: Hazardous processes and events from glacier and permafrost areas: lessons from the Chilean and Argentinean Andes, Earth Surf. Process. Landforms, doi:10.1002/esp.3524, in press, 2014.

Iturrizaga, L.: New observations on present and prehistorical glacier-dammed lakes in the Shimshal valley (Karakoram Mountains), J. Asian Earth Sci., 25, 545-555, doi:10.1016/j.jsenes.2004.04.011, 2005.

Ives, J. D., Shrestha, B. R., and Mool, P. K.: Formation of Glacial Lakes in the Hindu Kush-Himalayas and GLOF Risk Assessment, International Centre for Integrated Mountain Development (ICIMOD), Kathmandu, 56 pp., 2010.

Klimeš, J., Benešová, M., Vilímek, V., Bouška, P., and Cochachin, A. R.: The reconstruction of a glacial lake outburst flood using HEC-RAS and its significance for future hazard assessments: an example from Lake 513 in the Cordillera Blanca, Peru, Nat. Hazards, 71, 1617-1638, doi:10.1007/s11069-013-0968-4, 2014.

Korup, O. and Tweed, F.: Ice, moraine, and landslide dams in mountainous terrain, Quaternary Sci. Rev., 26, 3406-3422, doi:10.1016/j.quascirev.2007.10.012, 2007.

Lliboutry, L., Morales, B. A., Pautre, A., and Schneider, B.: Glaciological problems set by the control of dangerous lakes in Cordillera Blanca, Peru, I. Historical failures of moranic dams, their causes and prevention, J. Glaciol., 18, 239-254, 1977.

McKillop, R. J. and Clague, J. J.: Statistical, remote sensingbased approach for estimating the probability of catastrophic drainage from moraine-dammed lakes in southwestern British Columbia, Global Planet. Change, 56, 153-171, doi:10.1016/j.gloplacha.2006.07.004, 2007a.

McKillop, R. J. and Clague, J. J.: A procedure for making objective preliminary assessments of outburst flood hazard from morainedammed lakes in southwestern British Columbia, Nat. Hazards, 41, 131-157, doi:10.1007/s11069-006-9028-7, $2007 \mathrm{~b}$.

Mergili, M. and Schneider, J. F.: Regional-scale analysis of lake outburst hazards in the southwestern Pamir, Tajikistan, based on remote sensing and GIS, Nat. Hazards Earth Syst. Sci., 11, 14471462, doi:10.5194/nhess-11-1447-2011, 2011.

O’Connor, J. E., Hardison, J. H., and Costa, J. E.: Debris flows from failures of Neoglacial-age moraine dams in the Three Sisters and Mount Jefferson Wilderness areas, Oregon, U.S., US Geological Survey, Reston (Virginia), 93 pp., 2001.

Oppenheim, V.: Sobre las lagunas de Huaráz, in: Boletin de la sociedad geologica del Peru, Sociedad geologica del Peru, Lima, 68-80, 1946.

Quincey, D. J., Richardson, S. D., Luckman, A., Lucas, R. M., Reynolds, J. M., Hambrey, M. J., and Glasser, N. F.: Early recognition of glacial lake hazards in the Himalaya using remote sensing datasets, Global Planet. Change, 56, 137-152, doi:10.1016/j.gloplacha.2006.07.013, 2007.

Reynolds, J. M.: Development of glacial hazard and risk minimisation protocols in rural environments: Methods of glacial hazard assessment and management in the Cordillera Blanca, Peru, Reynolds Geo-Sciences Ltd., Flintshire (UK), 72 pp., 2003.
Rhea, S., Hayes, G., Villaseñor, A., Furlong, K. P., Tarr, A. C., and Benz, H. M.: Seismicity of the earth 1900-2007: Nazca Plate and South America (1:12000 000), US Geological Survey OpenFile Report 2010-1083-E, 1 sheet., 2010.

Richardson, S. D. and Reynolds, J. M.: An overview of glacial hazards in the Himalayas, Quaternary Int., 65, 31-47, doi:10.1016/S1040-6182(99)00035-X, 2000a.

Richardson, S. D. and Reynolds, J. M.: Degradation of ice-cored moraine dams: implications for hazard development, in: Debriscovered Glaciers, edited by: Nakawo, M., Raymond, C. F., and Fountain, A., 187-197, 2000b.

Solomina, O., Jomelli, V., Kaser, G., Ames, A., Berger, B., and Pouyaud, B.: Lichenometry in the Cordillera Blanca, Peru: "Little Ice Age" moraine chronology, Global Planet. Change, 59, 225-235, doi:10.1016/j.gloplacha.2006.11.016, 2007.

Thompson, L., Mosley-Thompson, E., and Henderson, K.: Ice-core palaeoclimate records in tropical South America since the las glacial maximum, J. Quaternary Sci., 15, 377-394, 2000.

Torres, E. and Brottger, A.: Estudio del segundo aluvion del Artesoncocha. Ministerio di fomento, Comision de control lagunas Cordillera Blanca, Huaráz, Peru, 3 pp., 1951.

Vilímek, V., Zapata, M. L., Klimeš, J., Patzelt, Z., and Santillán, N.: Influence of glacial retreat on natural hazards of the Palcacocha Lake area, Peru, Landslides, 2, 107-115, doi:10.1007/s10346005-0052-6, 2005.

Wang, W., Yao, T., Gao, Y., Yang, X., and Kattel, D. B.: A Firstorder Method to Identify Potentially Dangerous Glacial Lakes in a Region of the Southeastern Tibetan Plateau, Mountain Res. Develop., 31, 122-130, doi:10.1659/MRD-JOURNAL-D10-00059.1, 2011.

Wang, X., Liu, S., Guo, W., and Xu, J.: Assessment and simulation of glacier lake outburst floods for Longbasaba and Pida lakes, China, Mountain Res. Develop., 28, 310-317, doi:10.1659/mrd.0894, 2008.

Wang, X., Liu, S., Ding, Y., Guo, W., Jiang, Z., Lin, J., and Han, Y.: An approach for estimating the breach probabilities of moraine-dammed lakes in the Chinese Himalayas using remotesensing data, Nat. Hazards Earth Syst. Sci., 12, 3109-3122, doi:10.5194/nhess-12-3109-2012, 2012.

Westoby, M. J., Glasser, N. F., Brasington, J., Hambrey, M. J., Quincey, D. J., and Reynolds, J. M.: Modelling outburst floods from moraine-dammed glacial lakes, Earth-Sci. Rev., 134, 137159, doi:10.1016/j.earscirev.2014.03.009, 2014.

Worni, R., Huggel, C., and Stoffel, M.: Glacial lakes in the Indian Himalayas - From an area-wide glacial lake inventory to on-site and modeling based risk assessment of critical glacial lakes, Sci. Total Environ., 468-469, S71-S84, doi:10.1016/j.scitotenv.2012.11.043, 2013.

Yamada, T.: Glacier lakes and their outburst floods in the Nepal, Himalaya. Water and energy comission secretariat, Kathmandu, 37 pp., 1993.

Zapata, M. L.: La dinamica glaciar en lagunas de la Cordillera Blanca, Acta Montana (ser. A Geodynamics), 19, 37-60, 2002. 